\title{
New insects from the Kungurian of Tshekarda fossil site in Permian Territory of Russia
}

\section{Новые насекомые (Insecta) из кунгурского местонахождения Чекарда в Пермском крае}

\author{
Danil S. Aristov ${ }^{1} \&$ Alexandr P. Rasnitsyn ${ }^{1,2}$ \\ А.С. Аристов, А.П. Расниџын
}

\footnotetext{
${ }^{1}$ A.A. Borisyak Paleontological Institute, Russian Academy of Science, Profsoyuznaya, 123, 117997, Moscow, Russia. E-mail: danil_aristov@mail.ru.

Палеонтологический институт им. А.А. Борисяка РАН, Профсоюзная 123, 117997, Москва Россия.

${ }^{2}$ Natural History Museum, London S W7, 5 BD, England.
}

KEY WORDS: Insecta, Caloneurida, Hypoperlida, Chemidolestida, Grylloblattida, Phasmatida, Tshekarda, Permian, Kungurian Stage, new taxa.

КЛЮЧЕВЫЕ СЛОВА: Insecta, Caloneurida, Hypoperlida, Chemidolestida, Grylloblattida, Phasmatida, Чекарда, пермь, кунгурский ярус, новые таксоны.

ABSTRACT. New insect taxa are described from the Lower Permian (Kungurian) fossil site Tshekarda in the Permian Territory, Russia: Graticladus apiatus Aristov et Rasnitsyn, gen. et sp. n., Tshekardocladus sparsus Aristov et Rasnitsyn, gen. et sp. n. (Hypoperlida). Ascribed to Chemidolestida are Parmaptera permiana gen. et sp. n. (Parmapteridae fam.n.), to Grylloblattida Permoshurabia kungurica Aristov et Rasnitsyn, sp. n. (Geinitziidae); Parastenaropodites stirps Aristov et Rasnitsyn, sp. n. (Mesorthopteridae); Chelopterum ultimum Aristov et Rasnitsyn, sp. n. (Chelopteridae); Novokshonovus ignoratus Aristov et Rasnitsyn, gen. et sp. n. (Atactophlebiidae); Jubala gen. n. (Euryptilonidae; type species Sylvardembia pectinata Novokshonov, 2000). Nymphal Arachnophasma scurra Aristov et Rasnitsyn, gen. et sp. n. is attributed to Phasmatida (Permophasmatidae), and larval Cavalarva caudata Aristov et Rasnitsyn, gen. et sp. n. is described as Holometabola ordinis incertis.

РЕЗЮМЕ. Из нижнепермского местонахождения Чекарда (Россия, Пермский край; кунгурский ярус) описаны новые представители Hypoperlida, Chemidolestida, Grylloblattida, Phasmatida и Holometabola ordinis incertis. Описаны новые насекомые - Graticladus apiatus Aristov et Rasnitsyn, gen. et sp. n., Tshekardocladus sparsus Aristov et Rasnitsyn, gen. et sp. n. (Hypoperlida). K Chemidolestida отнесена Parmaptera permiana gen. et sp. n. (Parmapteridae fam.n.), к Grylloblattida Permoshurabia kungurica Aristov et Rasnitsyn, sp. n. (Geinitziidae); Parastenaropodites stirps Aristov et Rasnitsyn, sp. n. (Mesorthopteridae); Chelopterum ultimum Aristov et Rasnitsyn, sp. n. (Chelopteridae); Novokshonovus ignoratus Aristov et Rasnitsyn, gen. et sp. n. (Atactophlebiidae); Jubala gen. n. (Euryptilonidae; типовой вид Sylvardembia pectinata Novokshonov, 2000). K Phasmatida отнесена нимфа Arachnophasma scurra Aristov et Rasnitsyn, gen. et sp.n. (Permophasmatidae), личинка Cavalarva caudata Aristov et Rasnitsyn, gen. et sp. n. описана как Holometabola ordinis incertis.

\section{Introduction}

The famous lagerstetteTshekarda has yielded the richest fossil record of the Permian insects worldwide. Totally, found in deposits of Koshelevka Formation of the Kungurian) uppermost Lower Permian) at Sylva River in Urals are more than 8000 insect fossils ascribed to 25 orders, 99 families, 200 genera and 257 species [Novokschonov, 1998; Aristov, 2015], and described herein. Less than two decades ago the respective figures were 24, 65, 120 and 163, and the recent figures (above) are minimal yet because identification of the material accumulated is still in progress. No doubts, the number of insect taxa existed during Kungurian time is much higher than the above figures, and yet the level of our knowledge of Tshekarda fauna is comparatively high. Expected number of the Kungurian insect families (that is, all those actually recorded there plus recorded both before and after Kungurian) is 115 [Rasnitsyn et al., 2015]. As a result, 99 families actually recorded in Tshekarda (and in other deposits of Koshelevka Fm.) account for 86 per cent of those expected there. To 
compare, another richest Early Permian insect assemblage of the Wellington Formation (Artinskian Stage of Elmo and Midco in USA) includes 200 species, 106 genera, 53 families and 21 order, in spite that it is known after 23000 fossil, three times as many as in Koshelevka deposits [Beckemeyer \& Hall, 2007]. Being normalized by the logarithm of the number of specimens collected to counterbalance a disparity of volume of the material [cf. Rasnitsyn et al., 2013], diversity of the Tshekarda insect assemblage at the family level is found to be one and a half time as high as in Elmo and Midco combined [Rasnitsyn et al., 2015].
High diversity of the Tshekarda insect assemblage is at least partially explainable by the unique preservational state of the fossils mostly represented by articulated corpses in contrast to the isolated wings dominating in other localities. This made possible to describe the insects with ill-preserved wings and terrestrial preimaginal insects extremely rare in majority of fossil sites.

Among 99 families known in Tshekarda (and other Koshelevka deposits) those recorded for the first time there are four times more common than the families displaying their last occurrences there (27 vs. 7 families, respectively), a common pattern for the Early Per-

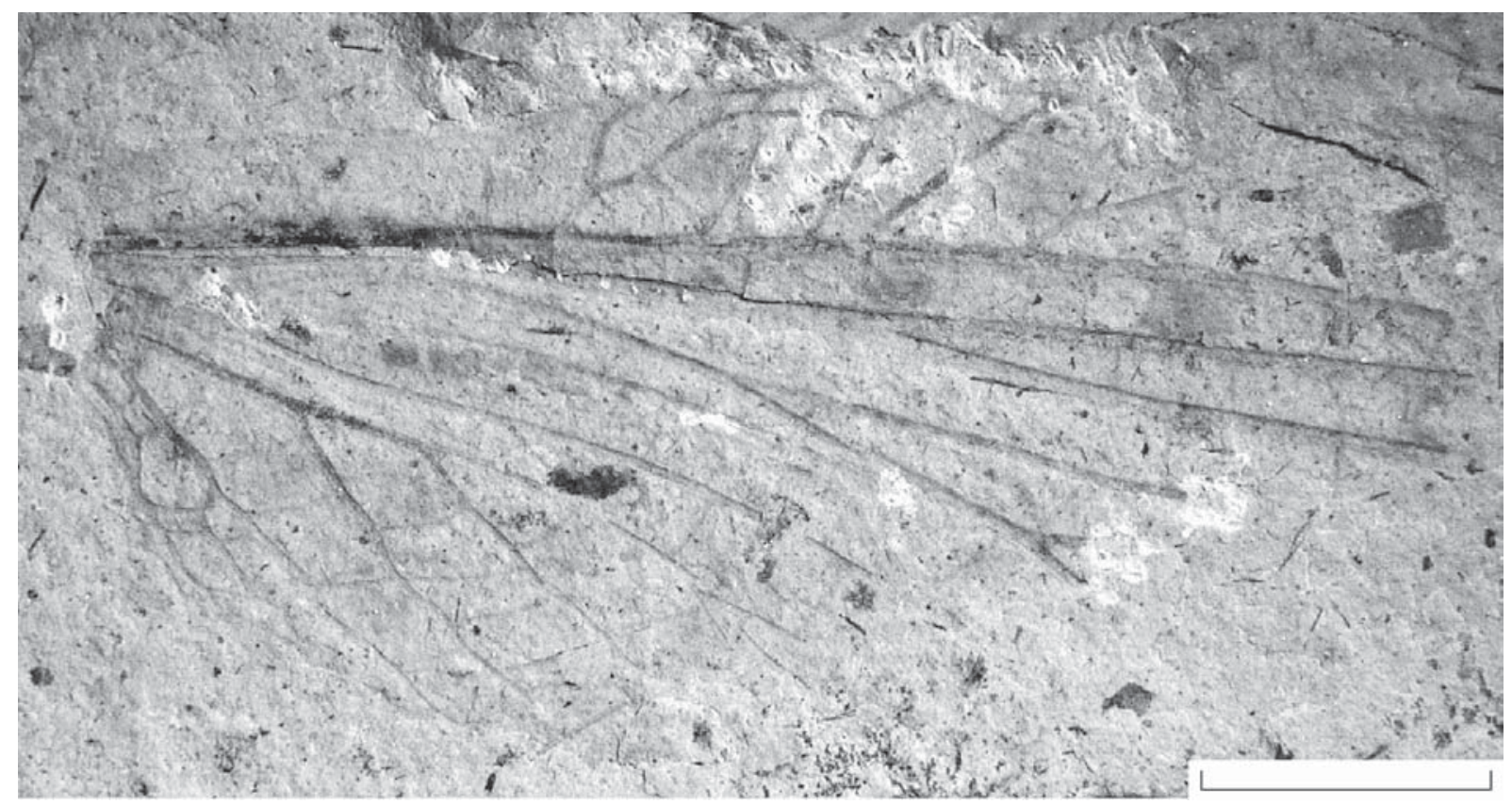

1

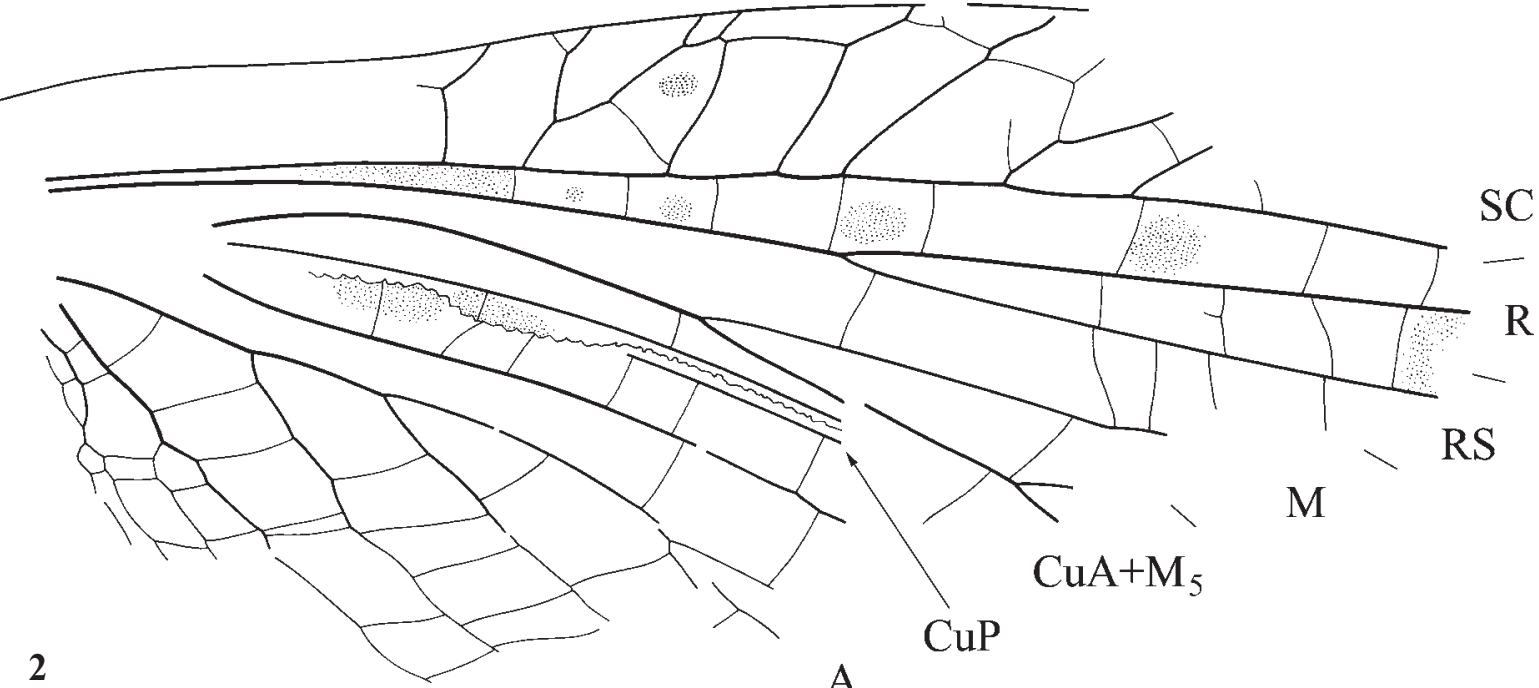

A

Figs 1-2. Graticladus apiatus Aristov et Rasnitsyn, sp. n., holotype PIN, № 4987/1002, fore wing: 1 - positive impression; 2 venation. Scale bars $5 \mathrm{~mm}$.

Рис. 1-2. Graticladus apiatus Aristov et Rasnitsyn, sp. n., голотип ПИН, № 4987/1002, переднее крыло: 1 — прямой отпечаток; 2 - жилкование. Длина масштабной линейки 5 мм. 
mian insect assemblages. 19 families are endemics of Tshekarda, 53 are in common with the next younger of the richest Permian assemblages, the Soyana one (the Kazanian of the northern European Russia), whilst only 37 of them are in common with the next older assemblage of Elmo and Midco [Rasnitsyn et al., 2015].

\section{Ordo Hypoperlida Martynov, 1928.}

Subordo Strephocladina Martynov, 1928

Family Ischnoneuridae Handlirsch, 1906

Genus Graticladus Novokschonov et Aristov, 2004

\section{Graticladus apiatus Aristov et Rasnitsyn, sp. n.} Figs 1-2.

MATERIAL. Holotype. PIN, no.4987/1002, part fossil of basal half of forewing; Tshekarda.

DESCRIPTION. Forewing $25 \mathrm{~mm}$ long as preserved, full length probably some $45-55 \mathrm{~mm}$. Membrane clear with small darker spots, regular in subcostal space and occasional in others. Costal space narrower basal and somewhat expanded distal, about 3 times as wide as subcostal at RS base. Subcostal veinlets forking and variously bent at connecting crossveins, otherwise crossveins where visible regular, simple, spaced for more than their length, more dense between $2 \mathrm{~A}$ branches, irregular behind basal $2 \mathrm{~A}$ branch. $\mathrm{M}_{5}$ base slightly basal RS base, $\mathrm{CuA}$ first fork somewhat distal RS base, $\mathrm{M}$ forking more distal. 1A not forking at level of $\mathrm{CuA}$ first fork, $2 \mathrm{~A}$ with $4^{\text {th }}$ fork at level of $\mathrm{M}_{5}$ base, $2 \mathrm{~A}$ branches weak and slightly zigzagged except basal.

DIAGNOSIS. Differs from the type species $G$. severus Novokschonov et Aristov, 2004 from Soyana (Lower Kazanian of Arkhangelsk Reg. in Russia) in having forewing membrane patterned, SC veinlets irregular at least in basal wing half, $\mathrm{M}$ branching more distal than $\mathrm{CuA}$, and $2 \mathrm{~A}$ branches more spaced and weakening distal, 5th branch if present much distal than $\mathrm{M}_{5}$ base. G. severus has forewing clear, SC branchlets simple and regular, $\mathrm{M}$ forking before $\mathrm{CuA}$, and $2 \mathrm{~A}$ branches strong throughout and with $5^{\text {th }}$ branch starting well before level of $\mathrm{M}_{5}$ base [Novokschonov \& Aristov, 2004]

ETYMOLOGY. Species name is the Latin for maculate.

\section{Family Tococladidae Carpenter, 1966.}

Genus Tshekardocladus Aristov et Rasnitsyn, gen. n.

TYPE SPECIES. Tsh. sparsus Aristov et Rasnitsyn, sp. $\mathbf{n}$.

DESCRIPTION. Forewing with SC veinlets regular, rarely forking (unknown for basalmost part), interradial space narrow basal, MA fore branch long, longitudinal before joining $\mathrm{RS}, \mathrm{M}_{5}$ oblique, aligned with $\mathrm{CuA}, \mathrm{CuA}$ neither forward nor backward pectinate (mid branch forked), 2A pectinate backward from behind its midlength, with subbasel fore branchlets.

DIAGNOSIS. Differs from both Tococladus Carpenter, 1966 and Opistocladus Carpenter, 1976 in having MA base and $\mathrm{M}_{5}$ both long, slanting, $\mathrm{CuA}$ irregularly branching, 2A branching late and with subbasal fore veinlets. Additionally differs from Opistocladus in more regular SC fore veinlets and, from majority species, in interradial space narrow basally. In Tococladus and Opistocladus $\mathrm{M}_{1}$ base and $\mathrm{M}_{5}$ both short and much less oblique, $\mathrm{CuA}$ regularly pectinate either forward (Tococladus) or backward (Opistocladus), 2A branching from before its midlength and with no fore branchlets; in Opistocladus basal SC veinlet subparallel to wing foremargin and so intercepting some other veinlets, and normally (except for a somewhat aberrant $O$. kargalensis Rasnitsyn et Aristov, 2013) with interradial space not narrowed basal.

COMPOSITION. Type species.

ETYMOLOGY. Genus name is after locality Tshekarda and genus Tococladus Carpenter, 1966. Gender masculine.

\section{Tshekardocladus sparsus Aristov et Rasnitsyn, sp. n.} Figs 3-5.

MATERIAL. Holotype. PIN, no.1700/292, forewing part and counterpart; Tshekarda.

DESCRIPTION. Forewing ca. $19 \mathrm{~mm}$ long. Membrane clear with indistinct small darker spots particularly in mediocubital and intercubital spaces. Two subapical SC and one apical R veinlets forked. RS+MA 7-branched, free MA 2branched, MP simple, CuA 4-branched (apical branch with short fork). Intercubital crossveins dense, oblique, mainly bent or sinuate. 5 anal veins present, $1 \mathrm{~A}$ with short apical fork, $2 \mathrm{~A}$ with 3 branches and 2 sinuate subbasal fore veinlets and subbasal oblique $2 \mathrm{a}-3 \mathrm{a}$ crossvein.

ETYMOLOGY. Species name is the Latin for freckled.

\section{Ordo Cnemidolestida Handlirsch, 1937 (sensu Aristov, 2014a)}

\section{Family Parmapteridae Aristov et Rasnitsyn, fam. n.}

TYPE GENUS. Parmaptera Aristov et Rasnitsyn, gen. n.

DESCRIPTION. Head small with large eyes. Pronotum with no paranota. Fore femur long, with longitudinal row of spines. Forewing with no precostal space. SC entering R. RS base at wing midlength, fused with MA. M branching at wing midlength, with $\mathrm{M}_{5}$ entering $\mathrm{CuA}$ after its first fork, $\mathrm{CuA}$ pectinate. Hind wing with costal space wider than subcostal, RS with many branches, $\mathrm{CuA}$ not angular near base.

DIAGNOSIS. Within Cnemidolestida the family is unique in having $\mathrm{M}_{5}$ entering $\mathrm{CuA}$ after its forking: all other Cnemidolestida have $\mathrm{M}_{5}$ enters $\mathrm{CuA}$ before it forks. Otherwise the new family is most similar to Spanioderidae in having SC meeting $\mathrm{R}$ combined with $\mathrm{M}$ forking at wing midlength and $\mathrm{CuA}$ pectinate regularly backward. It differs from majority of cnemidolestidans in having interradial space short and wide. In contrast, most Spanioderidae have interradial space long and narrow basally [Aristov, 2014a].

COMPOSITION. Type genus and Heterologus Carpenter, 1944 from the Carboniferous of USA and China.

REMARK. The family is attributed to Cnemidolestida in spite of $\mathrm{M}_{5}$ entering $\mathrm{CuA}$ after its forking which is considered an autapomorphy of the superorder Orthopteroidea [Gorochov, 2004] and is extremely rare beyond its limits. However, absence of precostal space, $\mathrm{SC}$ entering $\mathrm{R}$ instead of $\mathrm{C}$, and $\mathrm{CuA}$ pectinate backward exclude the new family from the Orthopteroidea. Pronotum lacking paranota, SC entering R instead of $\mathrm{C}$, and $\mathrm{CuA}$ pectinate backward are characteristic of the order Cnemidolestida [Aristov, 2014a], where the new family is placed herein.

\section{Genus Parmaptera Aristov et Rasnitsyn, gen. n.}

TYPE SPECIES. P. permiana Aristov et Rasnitsyn, sp. $\mathbf{n}$.

DESCRIPTION. Forewing with fore margin convex. Costal space 3.5 times as wide as subcostal space at RS base. $\mathrm{SC}$ with dense fore veinlets extended wing apical quarter. Interradial space much widened medial. $\mathrm{M}$ forking since shortly after $\mathrm{M}_{5}$, with three branches in wing apical third. $\mathrm{CuA}$ reaching wing distal quarter. $\mathrm{CuP}$ simple at least up to 

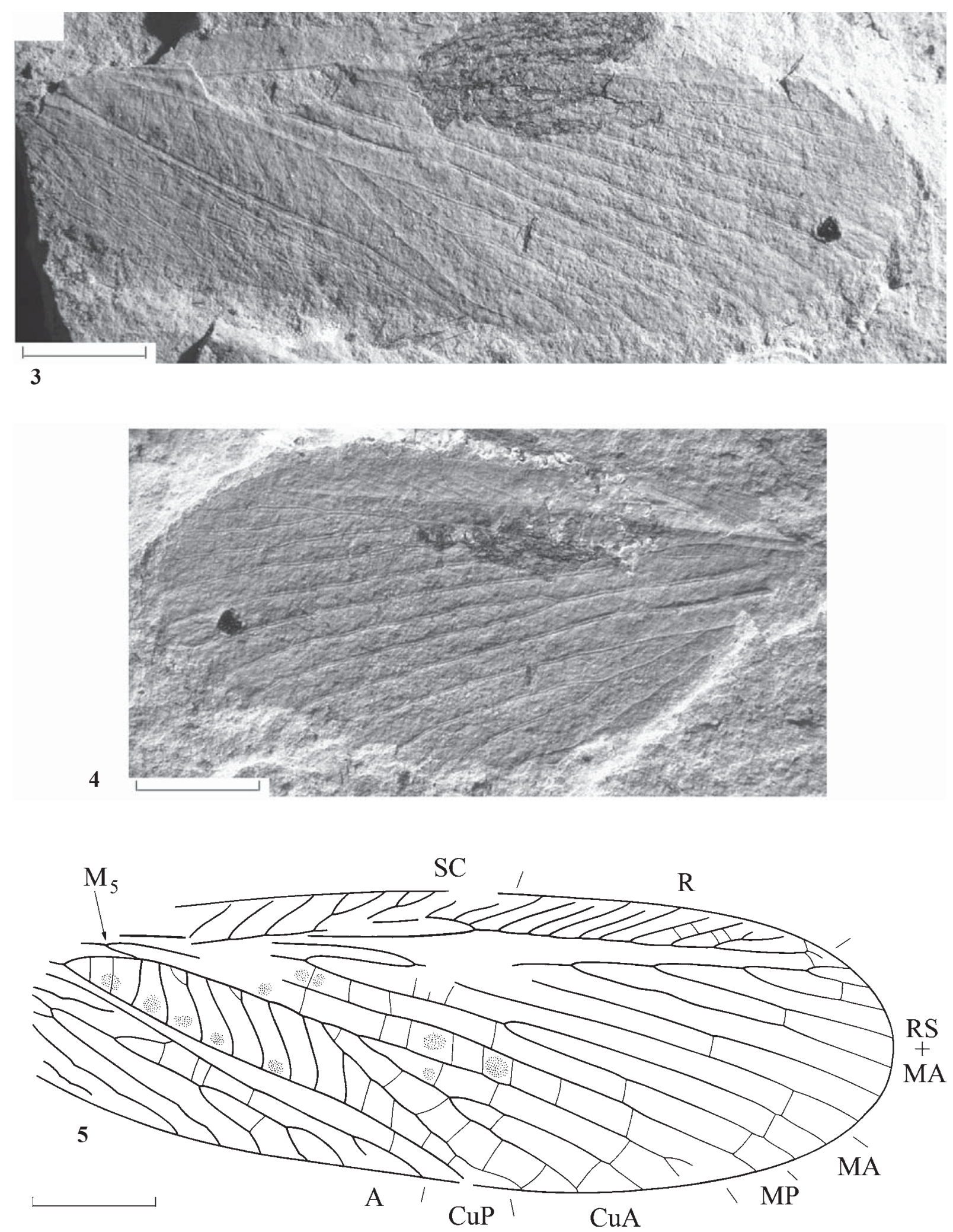

Figs 3-5. Tshekardocladus sparsus Aristov et Rasnitsyn, gen. et sp. n., Holotype. PIN, № 1700/292: 3 — positive impression; 4 negative impression; 5 - venation. Scale bars $3 \mathrm{~mm}$.

Рис. 3-5. Tshekardocladus sparsus Aristov et Rasnitsyn, gen. et sp. n., голотип. PIN, № 1700/292: 3 — прямой отпечаток; 4 обратный отпечаток; 5 - жилкование. Длина масштабной линейки 3 мм. 
its midlength. Crossveins simple, dense. Hind wing with SC entering $\mathrm{R}$ in distal quarter of wing. $\mathrm{R}$ gently bent basal, RS starting in wing basal quarter, polyneurous. $\mathrm{M}$ impoverished, branching behind wing midlength, $\mathrm{M}_{5}$ long, anal veins short. Crossveins simple, dense.

DIAGNOSIS. Differs from Heterologus in having RS less abundantly branching and with more distal position of its base, in short distance between $\mathrm{M}_{5}$ and first $\mathrm{M}$ fork, and in $\mathrm{M}$ entering $\mathrm{CuA}$ after the second $\mathrm{CuA}$ fork. Heterologus has RS polyneurous and starting more basal, $\mathrm{M}$ long between $\mathrm{M}_{5}$ and the first branching, $\mathrm{M}_{5}$ entering $\mathrm{CuA}$ after its first and not second fork [Carpenter, 1944; Béthoux et al., 2012].

COMPOSITION. Type species.

ETYMOLOGY. Genus name is after Parma, the former name of Perm region, and pteron the Greek for wing. Gender feminine.

\section{Parmaptera permiana Aristov et Rasnitsyn, sp. n.} Figs 6-9.

MATERIAL. Holotype. PIN, no.1700/4935, part and counterpart of complete insect; Tshekarda.

DESCRIPTION. Forewing ca. 60, hind wing ca. $55 \mathrm{~mm}$. long. Fore SC veinlets simple and Y-like, weakly bent. RS irregularly branching, with five or more branches. $\mathrm{CuA}$ with eight or more branches. A simple, $A_{2}$ probably with several branches. Hind wing with fore margin straight, RS with more than eight branches, $\mathrm{M}$ with more than two branches.

ETYMOLOGY. Species name is after the Permian Period.

\section{Ordo Grylloblattida Walker, 1914 \\ Subordo Grylloblattina Walker, 1914 \\ Family Geinitziidae Handlirsch, 1906 \\ Genus Permoshurabia Aristov, 2009}

Permoshurabia kungurica Aristov et Rasnitsyn, sp. n. Figs 10-12.

MATERIAL. Holotype. PIN, no.4987/1000, part and counterpart of complete insect; Tshekarda.

DESCRIPTION. Body 17, forewing 20, hind wing 17.5 $\mathrm{mm}$ long. Head large, hypognathous, with antennae filiform. Pronotum transverse, ovate, narrower than head, paranotal ring wide, with fore margin excised. Mesonotum transverse, with scutal lobes distinct, wide apart. Legs narrow, of medium length, fore and mid pairs of subequal length, hind legs somewhat longer. Abdomen short. Forewing with fore margin convex, costal space twice as wide as subcostal at RS base. SC with simple and forking veinlets, reaching apical wing third. R apex S-like bent, meeting wing fore margin. RS starting in basal wing third, irregularly branching in wing distal quarter. Interradial space slightly narrowing towards wing apex, with S-like bent crossveins. RS with 5 branches, with some of them meeting wing fore margin. MA and MP simple till apical wing third. $\mathrm{CuA}$ with two branches, $\mathrm{CuA}$ not S-like bent. Crossveins simple or forming two rows of cells. Hind wing with SC and R S-like bent basal, RS pectinate backwards, $\mathrm{CuA}$ simple.

DIAGNOSIS. The species is attributed to Permoshurabia based on RS branched irregularly and $\mathrm{CuA}_{2}$ straight. New species differs from the type P. mezenensis Aristov, 2009 from the Middle Permian (Lower Kazanian) of Soyana in Arkhangelsk Reg. in having SC long, interradial space gradually narrowing apical, and irregular branching of RS. In $P$. mezenensis $\mathrm{SC}$ does not reach wing apical third, interradial space is abruptly narrowing apical, and RS is dichotomous [Aristov, 2009].

ETYMOLOGY. Species name is after the Kungurian Stage.

Family Mesorthopteridae Tillyard, 1916

Genus Parastenaropodites Storozhenko, 1996

Parastenaropodites stirps Aristov et Rasnitsyn, sp. n. Figs 13-17.

MATERIAL. Holotype. PIN, no.1700/539, part and counterpart of complete insect; Tshekarda.

DESCRIPTION. Medium sized insect, with body 20 , forewing 18.5, and hind wing $16.5 \mathrm{~mm}$ long. Head large, hypognathous, with eyes small and antennae of medium length and short segments. Pronotum not large, slightly longer than wide, widening backward. Paranota narrow, widening backward. Mesonotum somewhat wider than long, scutum rather small, metanotum of similar structure. Legs cursory, with hind pair 1.5 times as long as fore one. Abdomen not reaching apices of folded wings. Forewing with fore margin slightly convex, costal space twice as wide as subcostal at RS base. SC reacing apical wing quarter, $\mathrm{SC}$ and $\mathrm{R}$ with fore veinlets simple, sparse. RS base in basal wing third, with short apical fork. Interradial space of near equal width throughout. MA and MP branching since behind wing midlength, MA with four and MP with two branches. CuA pectinate backward, with three main branches and five endings. Hind wing wide near apex. SC and $\mathrm{R}$ apices $\mathrm{S}$-like bent. $\mathrm{RS}$ pectinate forward, with four branches. $\mathrm{M}$ branching since wing midlength, three-branched. $\mathrm{CuA}$ branching in its basal third, two-branched.

DIAGNOSIS. The species is most similar to $P$. intricatus (Aristov, 2008) from the Middle Permian (Lower Kazanian) of Soyana in Arkhangelsk Reg. in narrow costal space combined with late branching of RS and backward pectinated $\mathrm{CuA}$. It differs from the latter in having interradial space wide basal and $\mathrm{CuA}$ impoverished. $P$. intricatus has interradial space narrow basal and $\mathrm{CuA}$ with 5-6 main forks [Aristov, 2014b].

ETYMOLOGY. Species name is the Latin for ancestor.

Family Euryptilonidae Martynov, 1940

Genus Jubala Aristov et Rasnitsyn, gen. n.

TYPE SPECIES. Sylvardembia pectinata Novokshonov, 2000.

DESCRIPTION. Head hypognathous, with eyes rather small and antenna thick. Pronotum rather small, trapezoid, narrowing backward. Paranotal ring wide, with no fore excision. Mesonotum transverse, metanotum elongate. Legs short, all three pairs of subequal length, tarsus five-segmented, with four basal segments short and fifth one as long as basal four together. Abdomen long and narrow. Forewing with fore margin slightly convex, costal space wider than subcostal one at RS base. SC reaching $\mathrm{C}$ before distal wing third. $\mathrm{R}$ with posterior branches. RS starting at wing midlength. $\mathrm{M}$ with free base, shortly fusing with $\mathrm{CuA}$ and farther distal to RS, with resulting composite vein running straight and close to $\mathrm{R}$ till slightly behind $\mathrm{C}$ apex and bearing very regular backward pecten of numerous oblique, parallel, mainly simple branches not identifiable as either $\mathrm{RS}, \mathrm{M}$, or $\mathrm{CuA}$. Intercubital space not widened. Crossveins simple, near straight, dense. Hind wing with fore margin straight, costal space wider than subcostal on if basal wing quarter, $\mathrm{R}$ base S-like bent.

DIAGNOSIS. The genus is placed in Euryptilonidae based on pronotum with paranota combined with RS bearing 

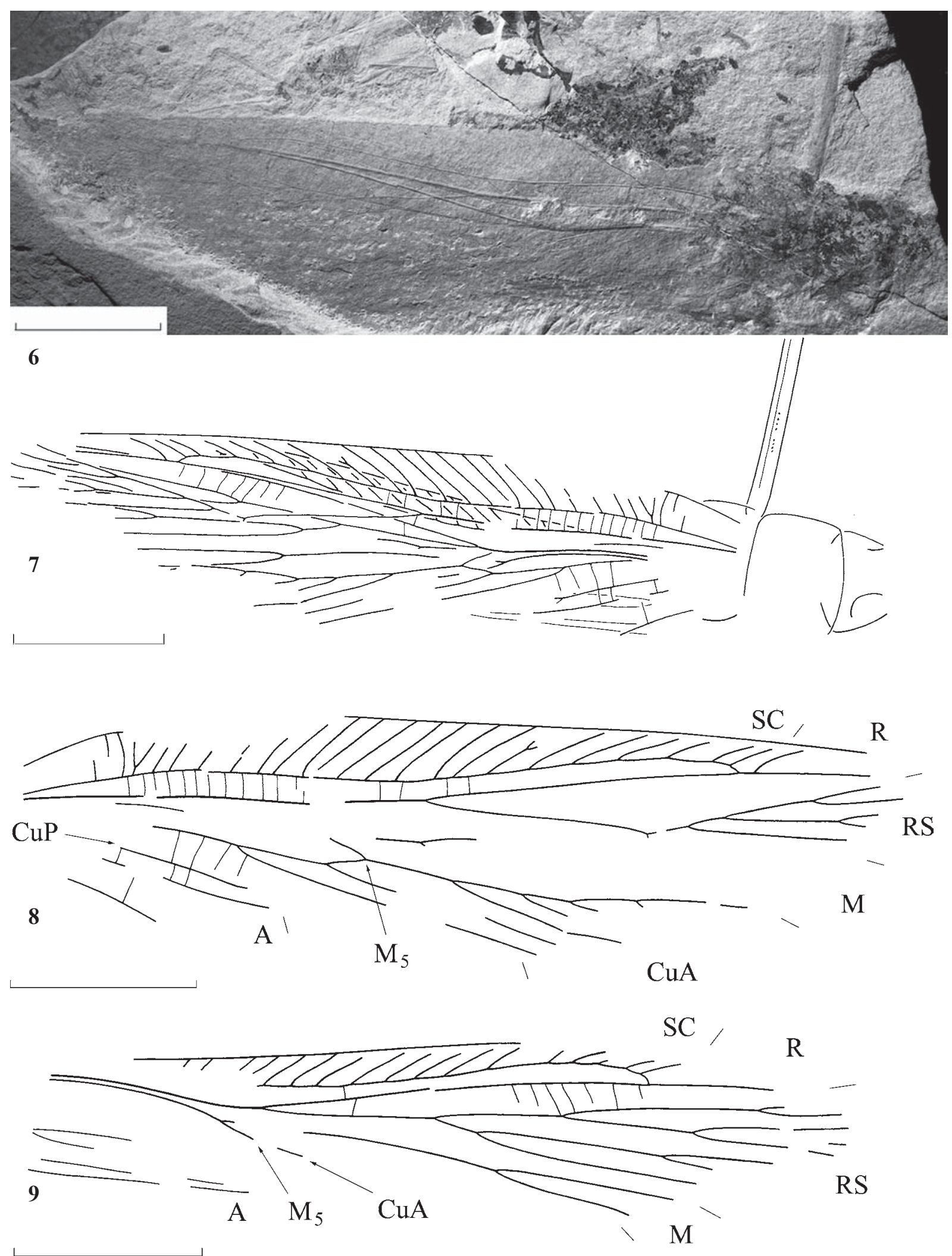

Figs 6-9. Parmaptera permiana Aristov et Rasnitsyn, gen. et sp. n., Holotype PIN, № 1700/4935: 6-7 — habitus; 8 — venation of fore wing; 9 - venation of hind wing. Scale bars $-10 \mathrm{~mm}$.

Рис. 6-9. Parmaptera permiana Aristov et Rasnitsyn, gen. et sp. n., голотип ПИН, № 1700/4935: 6-7 — общий вид, 8 — жилкование переднего крыла; 9 - жилкование заднего крыла. Длина масштабной линейки 10 мм. 


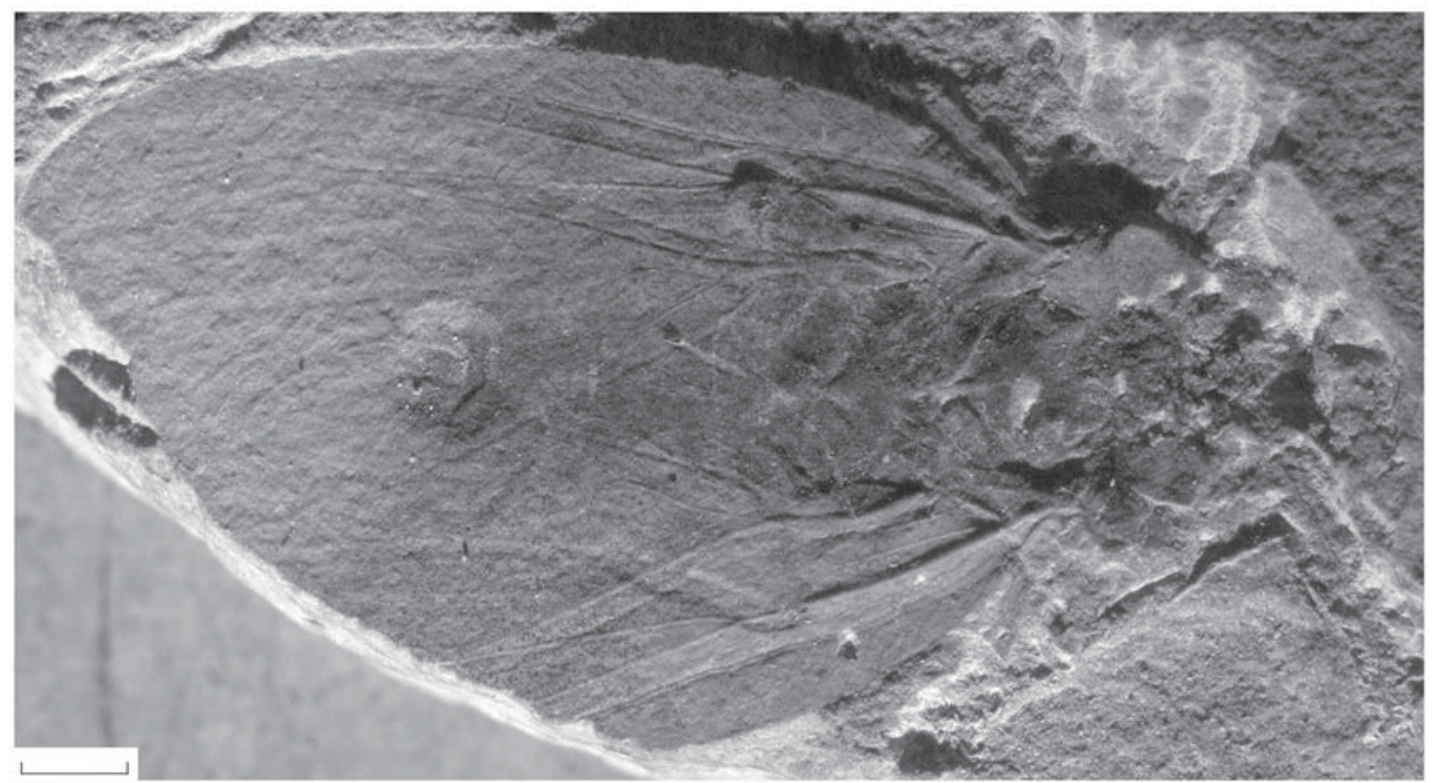

11

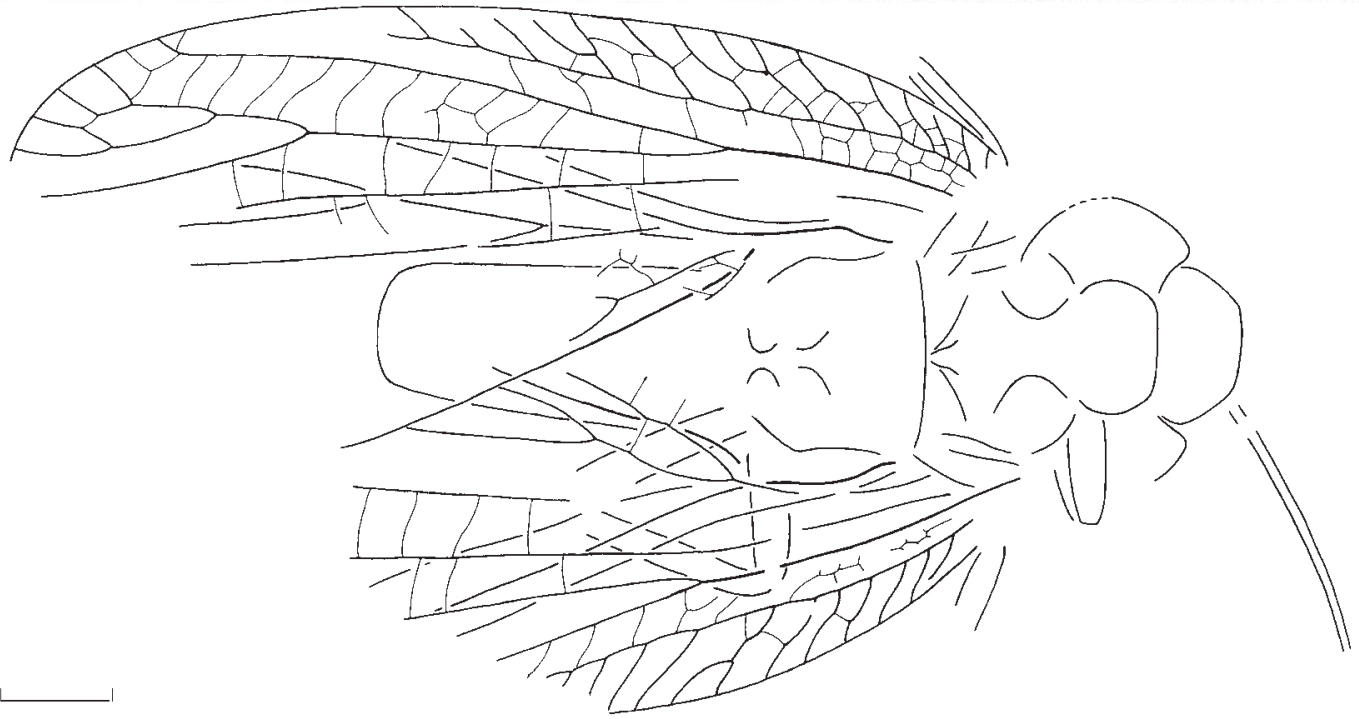

\section{$\mathrm{SC}$}

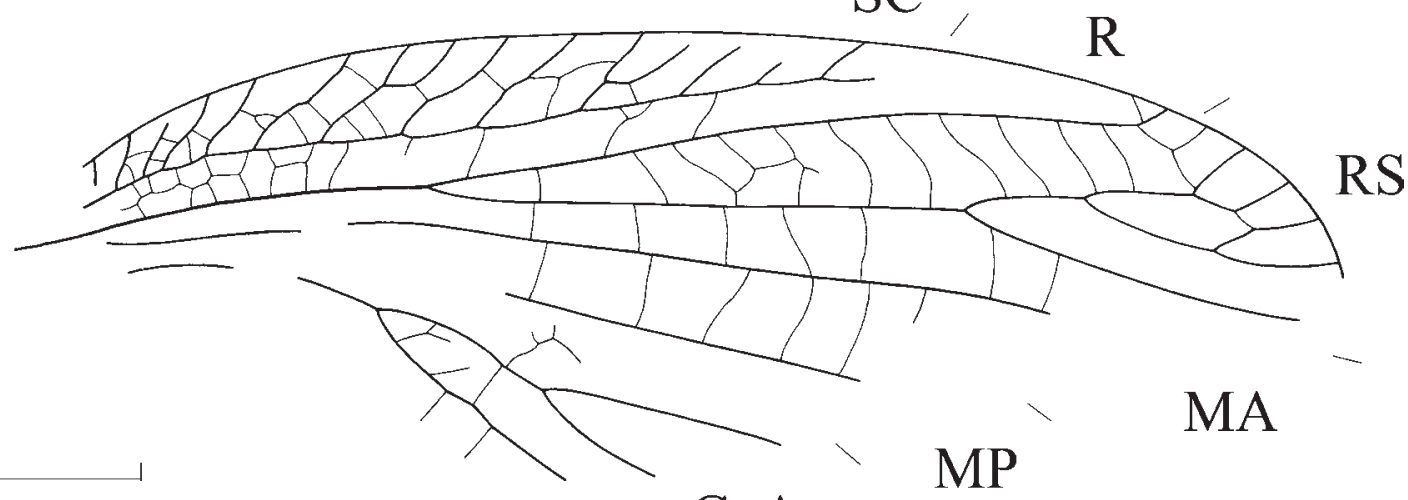

$\mathrm{CuA}$

Figs 10 -12. Permoshurabia kungurica Aristov et Rasnitsyn, sp. n.: Holotype PIN, № 4987/1000: 10-11 — general view, 12 — forewing venation restored based on the holotype fore and left wings. Scale bars -2 мм.

Рис. 10 -12. Permoshurabia kungurica Aristov et Rasnitsyn, sp. п.: голотип ПИН, № 4987/1000: 10-11 — общий вид, 12 — реконструкция переднего крыла на основе правого и левого крыльев голотипа. Длина масштабной линейки - 2 мм. 
back branches and $\mathrm{M}$ and $\mathrm{CuA}$ fused basal. It differs from the closest genus Euryptilon Martynov, 1940 from Tshekarda in having antenna longer and much thicker, paranotal ring lacking anterior excision, hind legs short, and RS, $\mathrm{M}$ amd $\mathrm{CuA}$ forming entire long, wide, and very regular comb. Euryptilon has antenna short and thin, paranotal ring excised forward, hind legs much longer than others, $\mathrm{M}$ and $\mathrm{CuA}$ fused basal to each other but not to RS, and do not form a regular comb [Aristov, 2011].

COMPOSITION. Type species.

ETYMOLOGY. Genus name from juba (lat.) - crista and ala (lat.) - wing.

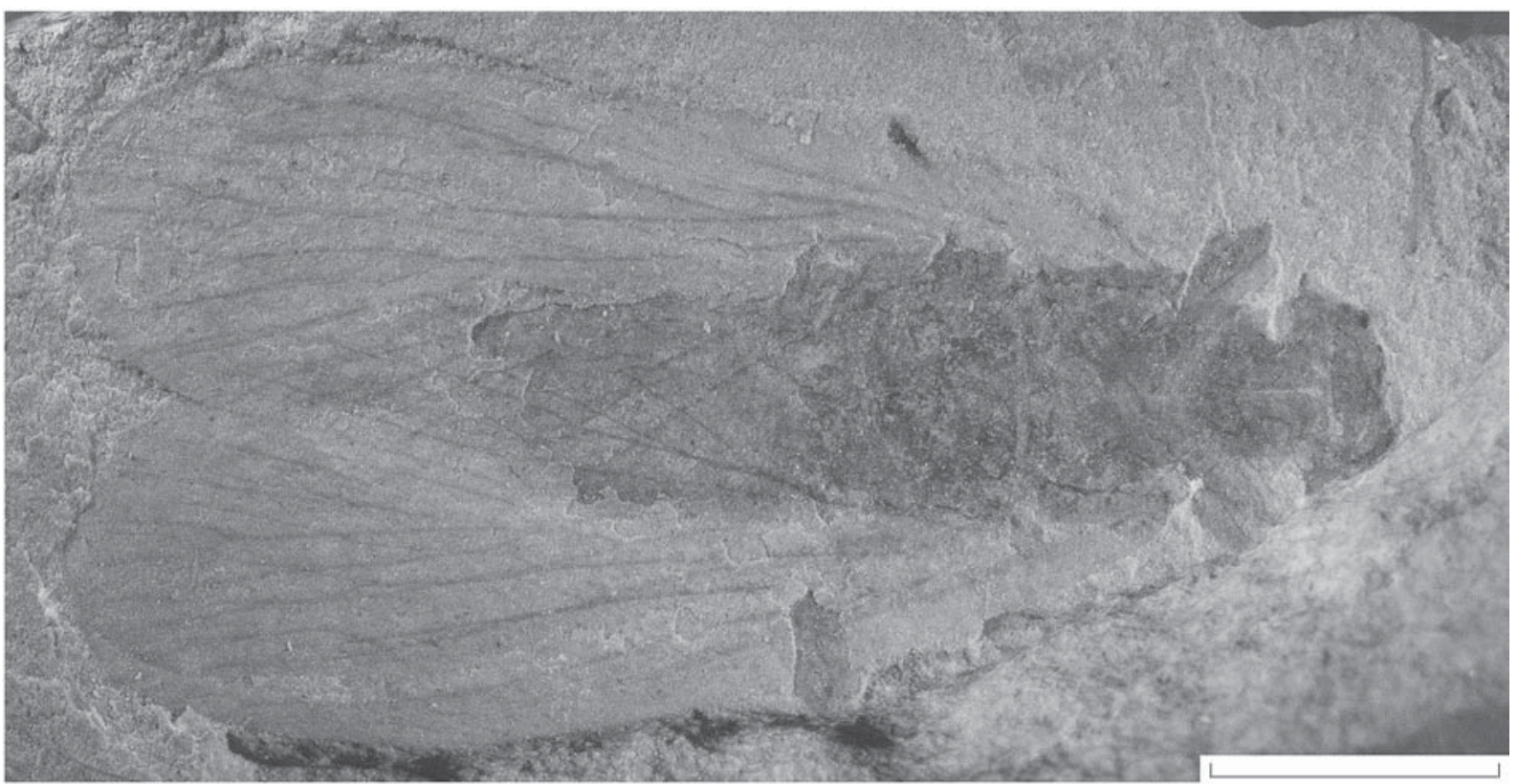

13

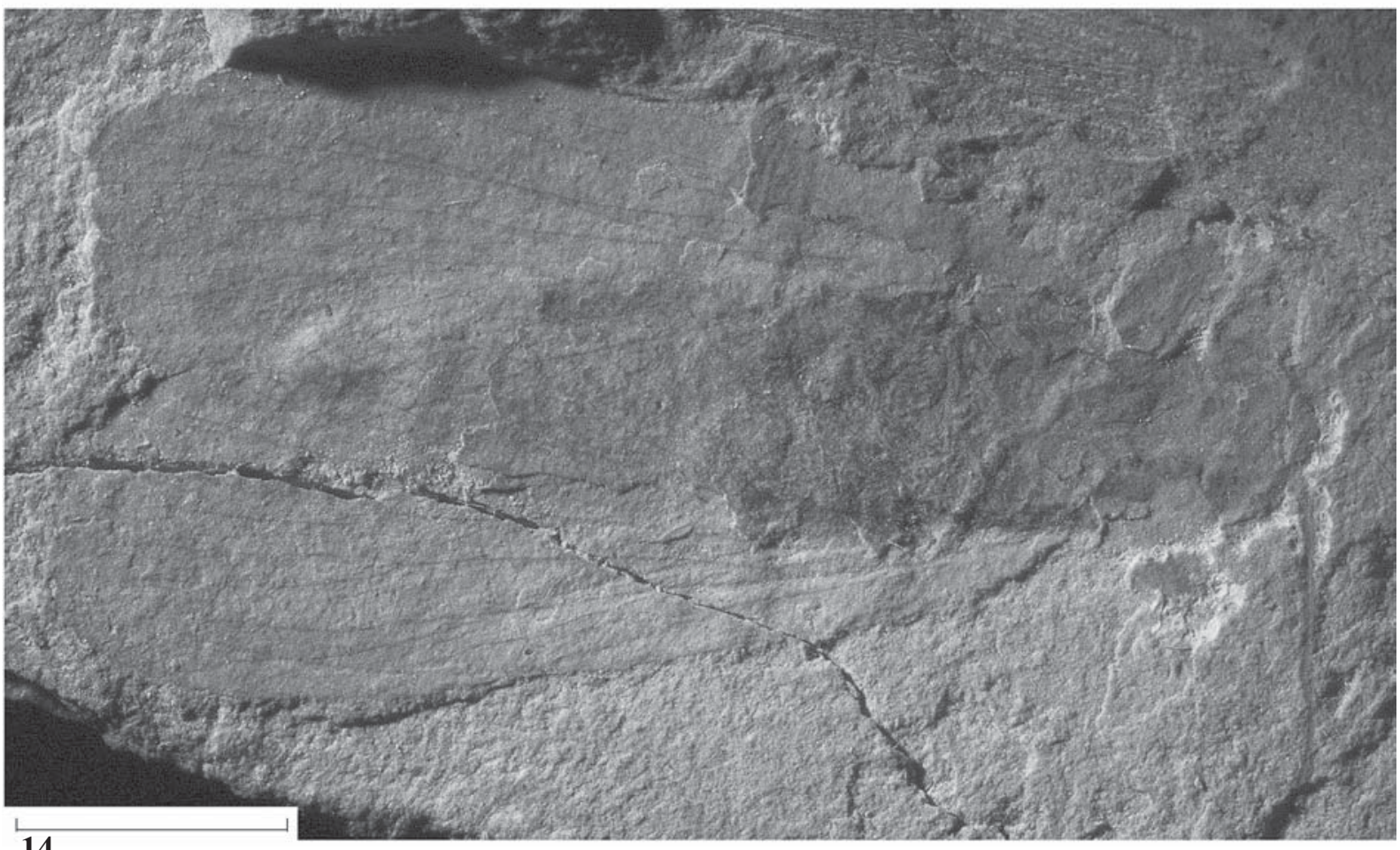

14

Figs 13-14. Parastenaropodites stirps Aristov et Rasnitsyn, sp. n.: Holotype PIN, № 1700/539, general view of positive and negative impression. Scale bars $-5 \mathrm{~mm}$.

Figs 13-14. Parastenaropodites stirps Aristov et Rasnitsyn, sp. n.: голотип ПИН, № 1700/539, общий вид прямого и обратного отпечатка. Длина масштабной линейки -5 мм. 


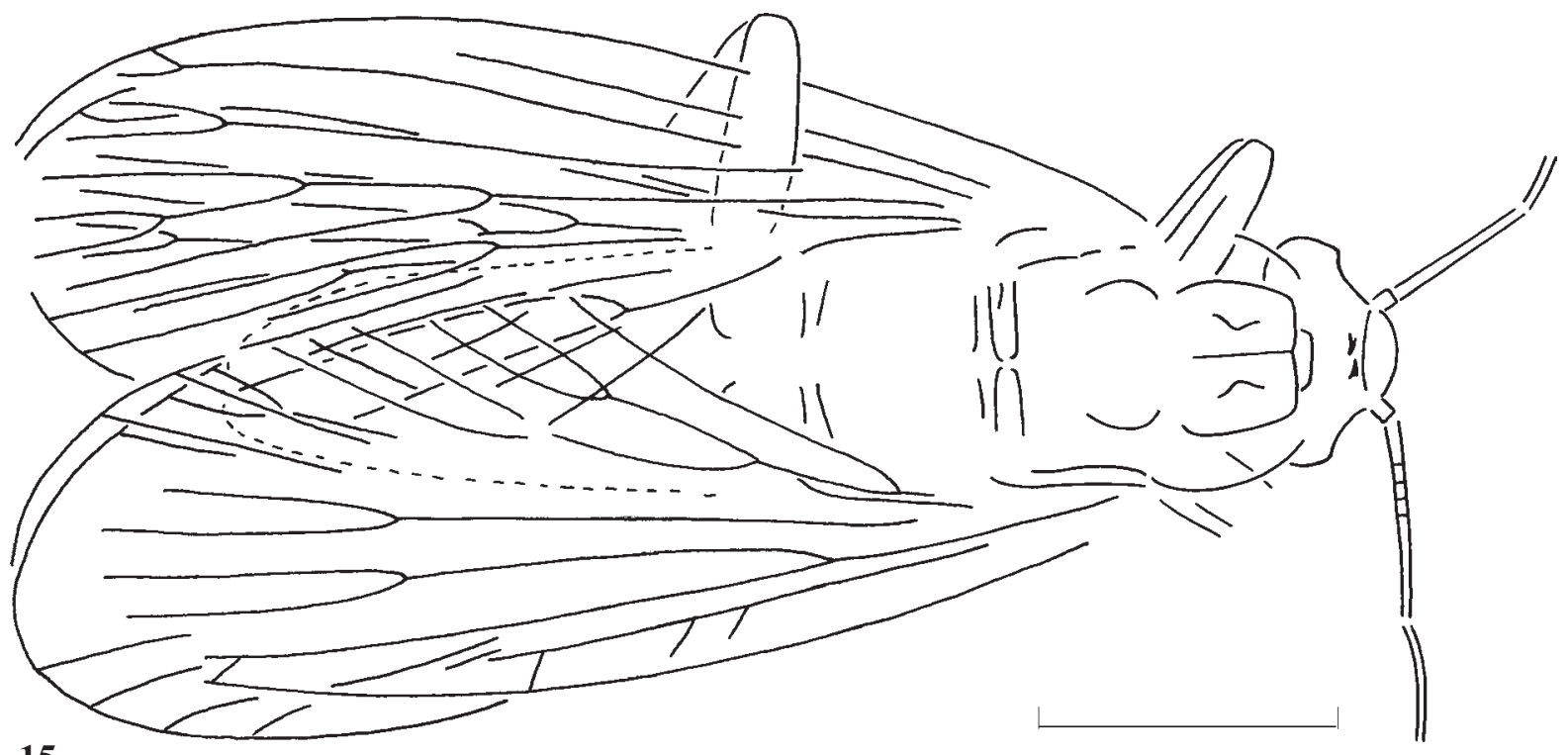

15
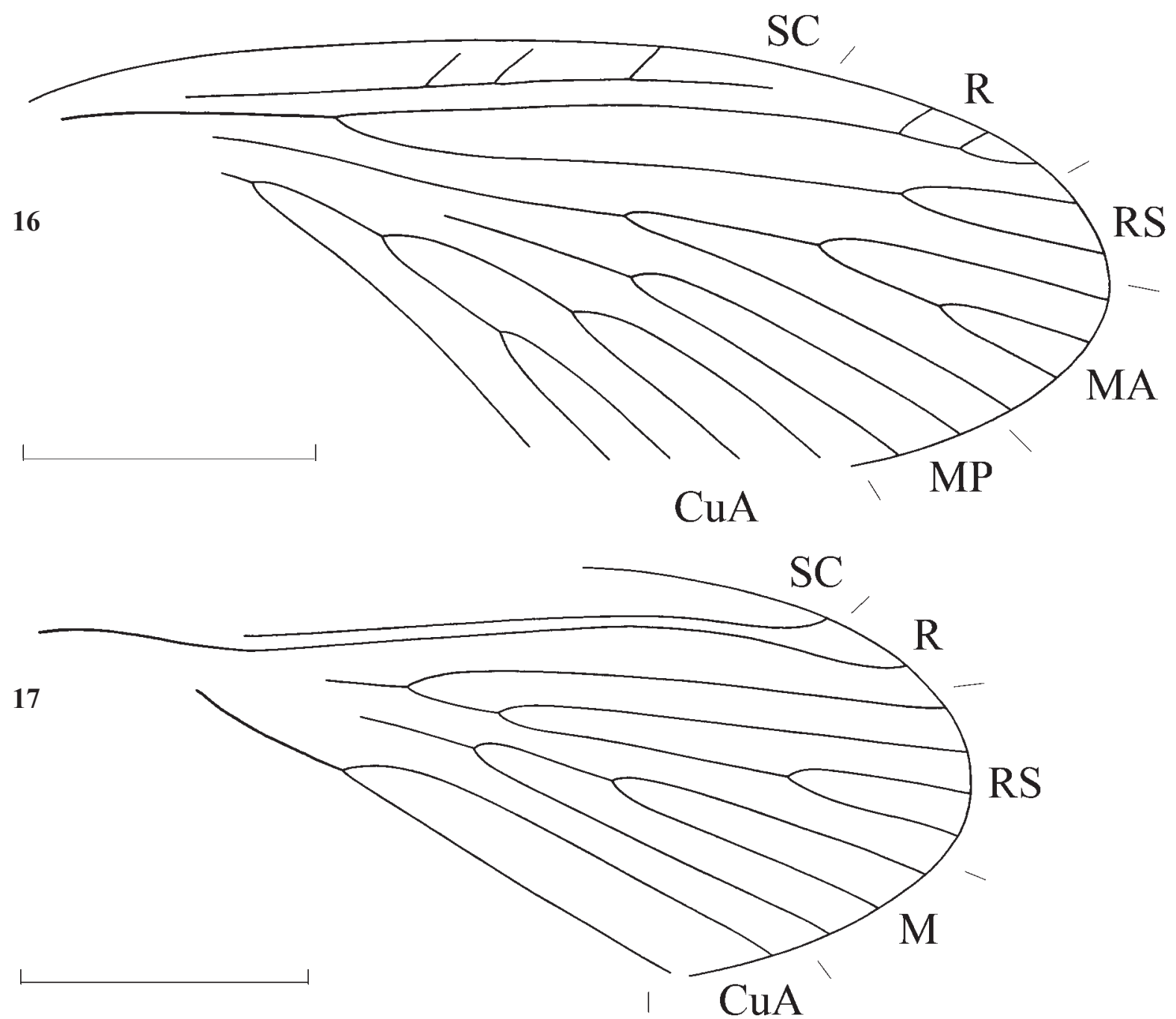

Figs 15-17. Parastenaropodites stirps Aristov et Rasnitsyn, sp. n.: Holotype PIN, № 1700/539: 15 — general view; 16 — venation of fore wing; 17 - venation of hind wing. Scale bars $-5 \mathrm{~mm}$.

Рис. 15-17. Parastenaropodites stirps Aristov et Rasnitsyn, sp. n.: голотип ПИН, № 1700/539: 15 — общий вид, 16 — жилкование переднего крыла; 17 - жилкование заднего крыла. Длина масштабной линейки -5 мм. 
Jubala pectinata (Novokshonov, 2000) comb. n. Figs 18-20.

Sylvardembia pectinata: Novokshonov, 2000: 44, fig. 2, a, tabl. IV, fig. 2.

MATERIAL. Holotype. PIN, no.1700/1012, forewing part and counterpart; Tshekarda and specimen PIN, no.1700/1080.

DESCRIPTION. Body length above $22 \mathrm{~mm}$, forewing 21 $\mathrm{mm}$, hindwing 18 long. SC and $\mathrm{R}$ with fore branchlets simple and $\mathrm{Y}$-like, $\mathrm{M}+\mathrm{CuA}$ with $7, \mathrm{RS}+\mathrm{M}+\mathrm{CuA}$ with 8 branches.

Family Chelopteridae Carpenter, 1950

Genus Chelopterum Carpenter, 1950

Chelopterum ultimum Aristov et Rasnitsyn, sp. n. Figs 21-25.
MATERIAL. Holotype. PIN, no.1700/539, part and counterpart of complete insect; Tshekarda.

DESCRIPTION. Medium sized insect, forewing 19, hind wing $17 \mathrm{~mm}$ long. Pronotum with paranotal ring complete, much narrowed behind. Mesonotum transverse, metanotum quadrate, big. Hind legs narrow, of medium length. Forewing with fore margin convex. SC reaching before wing midlength. Costal space 1.5 times as wide as subcostal one at RS base. $\mathrm{SC}$ and $\mathrm{R}$ with fore veinlets dense, interconnected with crossveins. RS starting just after wing basal third, with more than three branches. Interradial space wide, crossed with dense, S-like bent crossveins. M forking into MA and MP slightly before RS base. CuA branching near wing hind margin, pectinate forward. Crossveins simple and forming
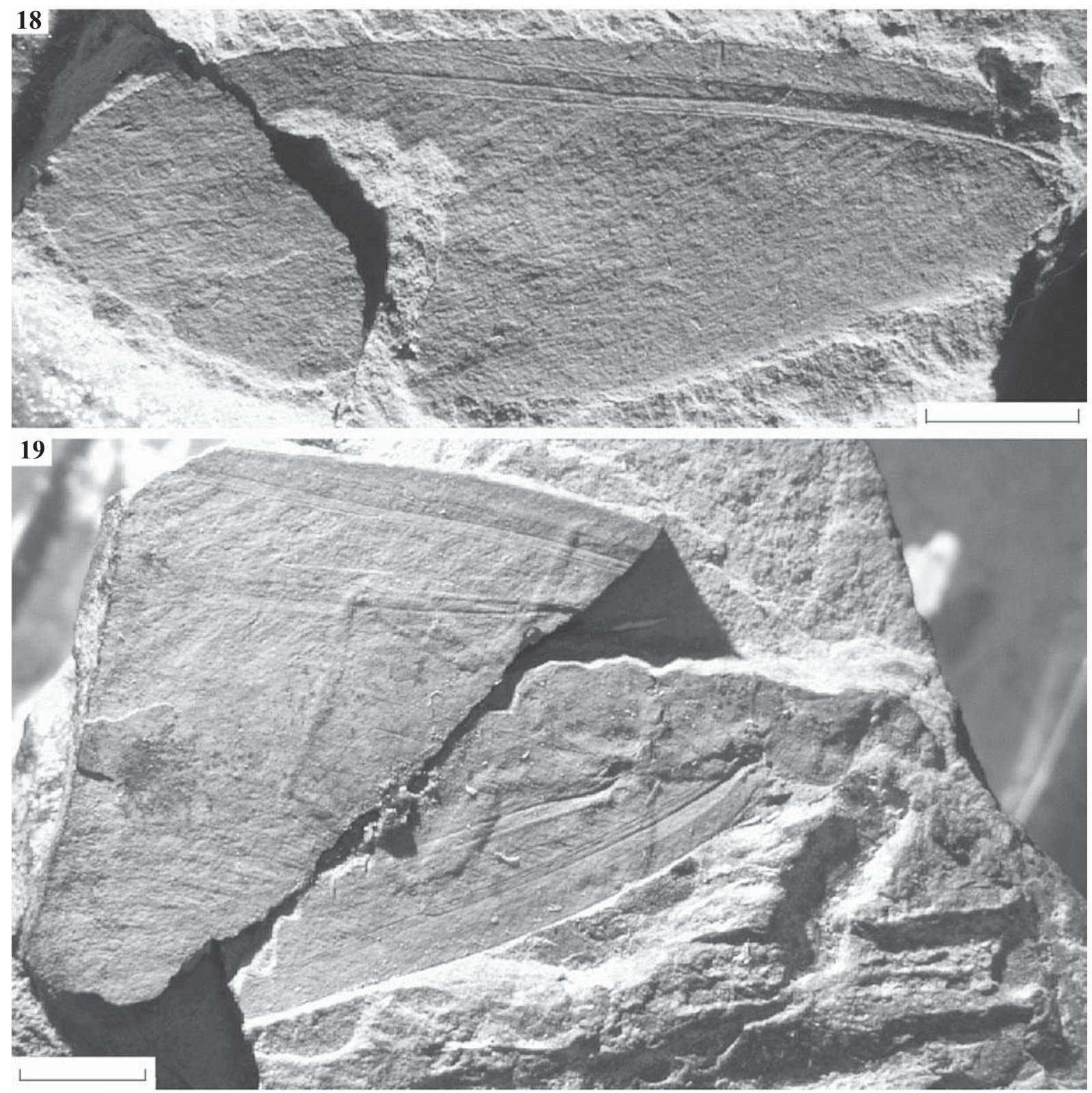

Figs 18-19. Jubala pectinata (Novokshonov, 2000), comb.n. 18 - Holotype PIN, № 1700/539, positive impression of fore wing; 19 - specimen PIN № 1700/1080, positive impression, general view. Scale bar - $5 \mathrm{~mm}$.

Рис. 18-19. Jubala pectinata (Novokshonov, 2000), comb.n.: 18 - голотип ПИН, № 1700/539, переднее крыло, прямой отпечаток; 19 - экз. ПИН, № 1700/1080, общий вид, прямой отпечаток. Длина масштабной линейки -5 мм. 
two rows af cells. Colour pattern as medium sized spots.

DIAGNOSIS. New species is attributed to Chelopterum based on dense interradial crossveins. Differs from the type species from the Artian (Lower Permian) of Elmo, USA, in having SC short and distal position of $\mathrm{M}$ fork. In Ch. peregrinum Carpenter, $1950 \mathrm{SC}$ reaches apical wing third and $\mathrm{M}$ forking into MA and MP well before RS base [Cui et al., 2011].

ETYMOLOGY. Species name is the Latin for last.

Family Atactophlebiidae Martynov, 1930

Genus Novokshonovus Aristov et Rasnitsyn, gen. n.

TYPE SPECIES. N. ignoratus, sp. $\mathbf{n}$.

DESCRIPTION. Forewing almost parallel-sided for most its length, with $\mathrm{SC}$ reaching near wing midlength. $\mathrm{R}$ with long fore branch starting before SC end. RS starting at wing midlength. $\mathrm{M}_{5}$ reaching $\mathrm{CuA}$ behind its first fork. $\mathrm{M}$ forking into MA and MP before RS base, in basal wing quarter. MP branching since near its base in basal wing third, its fore branch partially desclerotized. $\mathrm{CuA}$ not forking into $\mathrm{CuA}$ and $\mathrm{CuA}_{2}$, with basal branch simple, S-like bent basal.

DIAGNOSIS. New genus is closest to Kirkorella G. Zalessky, 1939 from Tshekarda in having short SC combined with late origin of RS and early branching MP. It differs from Kirkorella in wing not narrowing abruptly toward apex, $\mathrm{R}$ with long fore branch, and with basal $\mathrm{CuA}$ branch S-like bent basal. Unlike it, Kirkorella has forewing abruptly narrowed apical, $\mathrm{R}$ with short fore branches, and $\mathrm{CuA}$ base nor S-like bent near base [Storozhenko, 1998; Aristov, 2004].

COMPOSITION. Type species.

ETYMOLOGY. The name is in honor of paleoentomologist Viktor Novokshonov. Gender masculine.

Novokshonovus ignoratus Aristov et Rasnitsyn, sp. n. Figs 26-30.

MATERIAL. Holotype. PIN, no. 4987/811, forewing part and counterpart. Paratype. PIN, no. 4987/810; both from Tshekarda.

DESCRIPTION. Forewing length ca. $40 \mathrm{~mm}$. RS branching since distal wing quarter, with three branches. MA with four and MP with at least five branches, one of which not always reaching wing margin. $\mathrm{CuA}$ with posterior comb of four or five branches or forming two posterior combs of seven branches total. $\mathrm{A}_{1}$ with two or three, $\mathrm{A}_{2}$ with six to seven branches, of which fore one ending blind among crossveins. Crossveins simple or forming rows of cells..

ETYMOLOGY. The species name is the Latin for unrecognized.
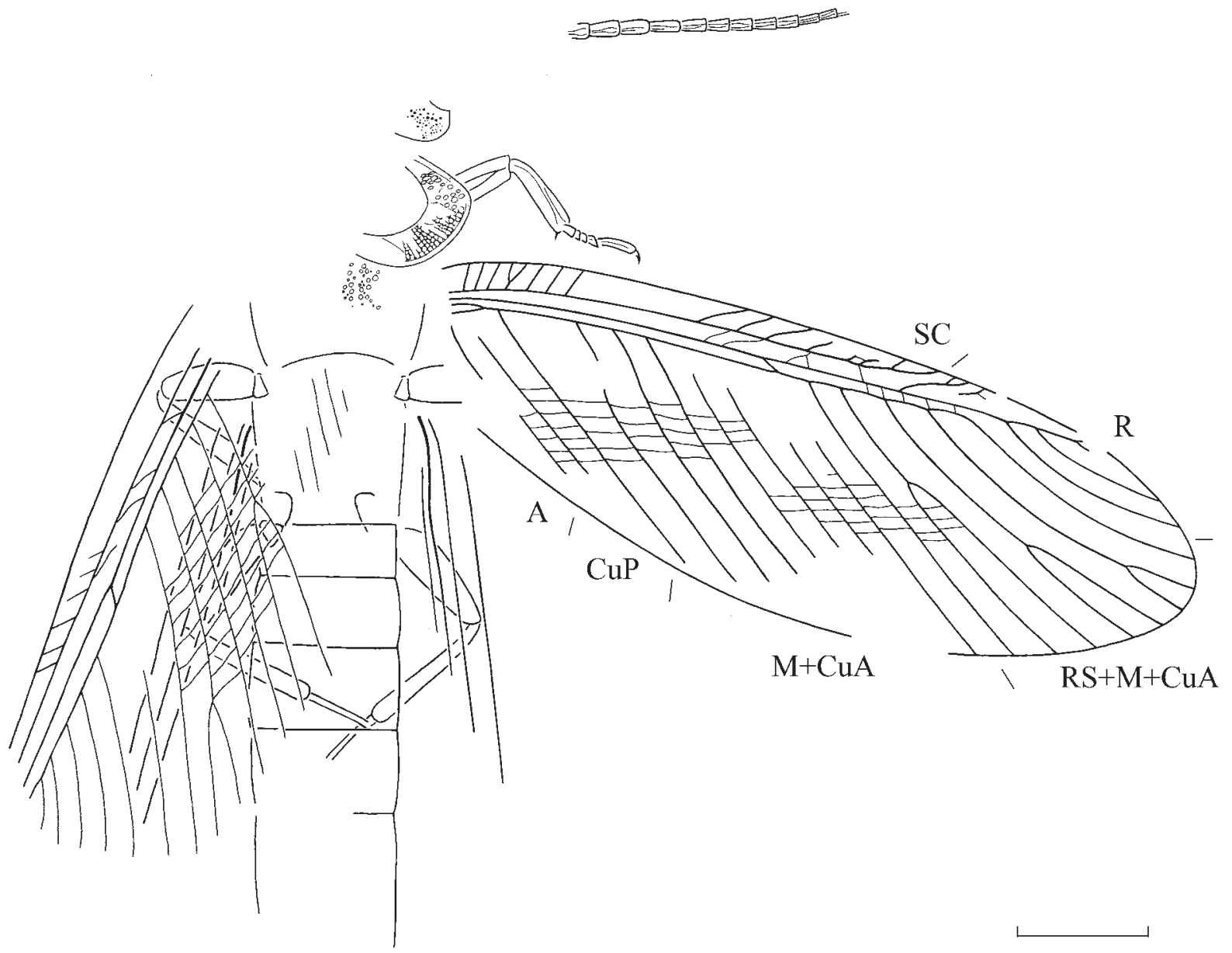

Fig. 20. Jubala pectinata (Novokshonov, 2000), comb.n., Restored based on holotype PIN, № 1700/539, and specimen PIN, № 1700/ 1080. Scale bar $-5 \mathrm{~mm}$.

Рис. 20 Jubala pectinata (Novokshonov, 2000), comb.n., реконструкция на основе голотипа ПИН, № 1700/539 и экз. ПИН, № 1700/ 1080. Длина масштабной линейки -5 мм. 


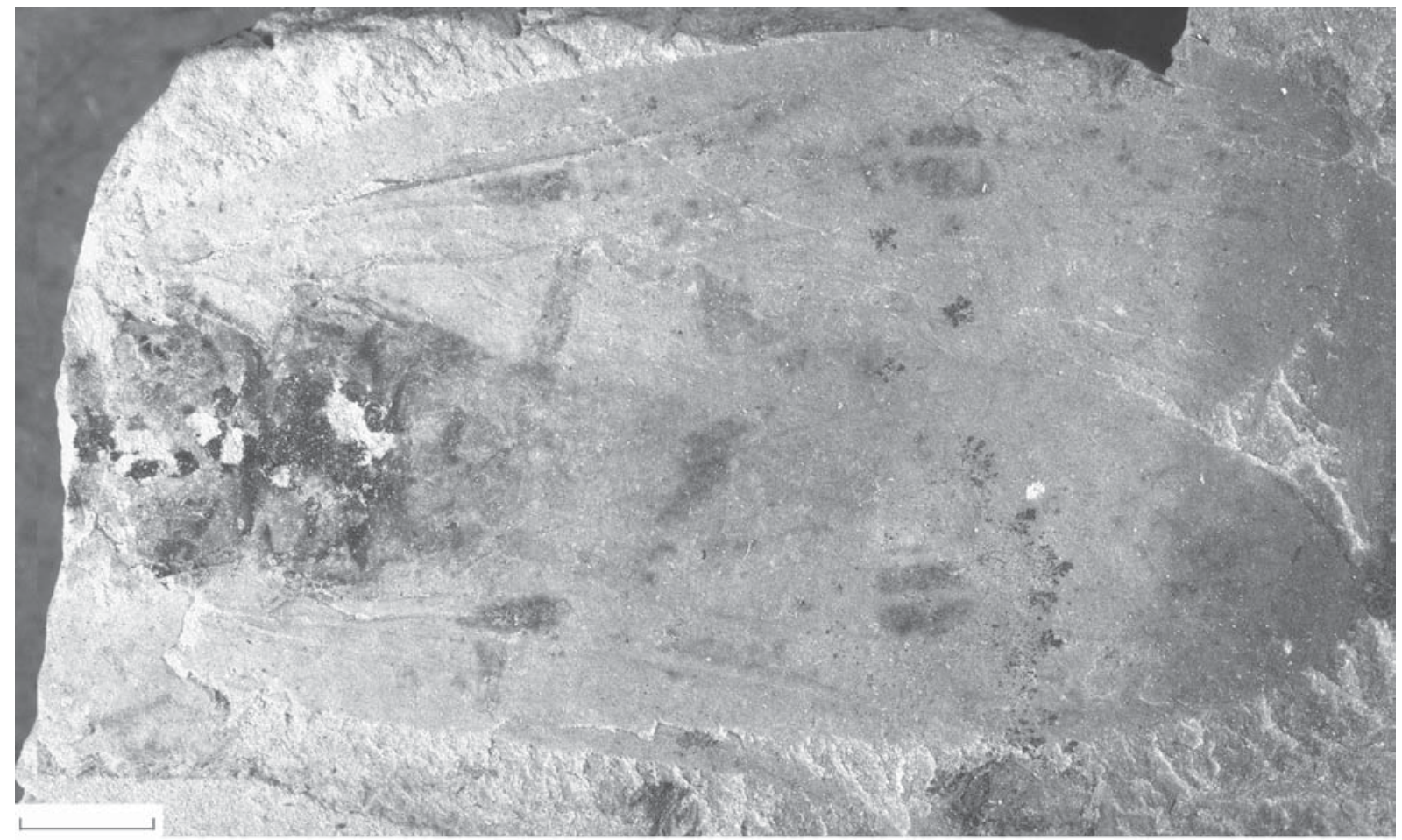

21

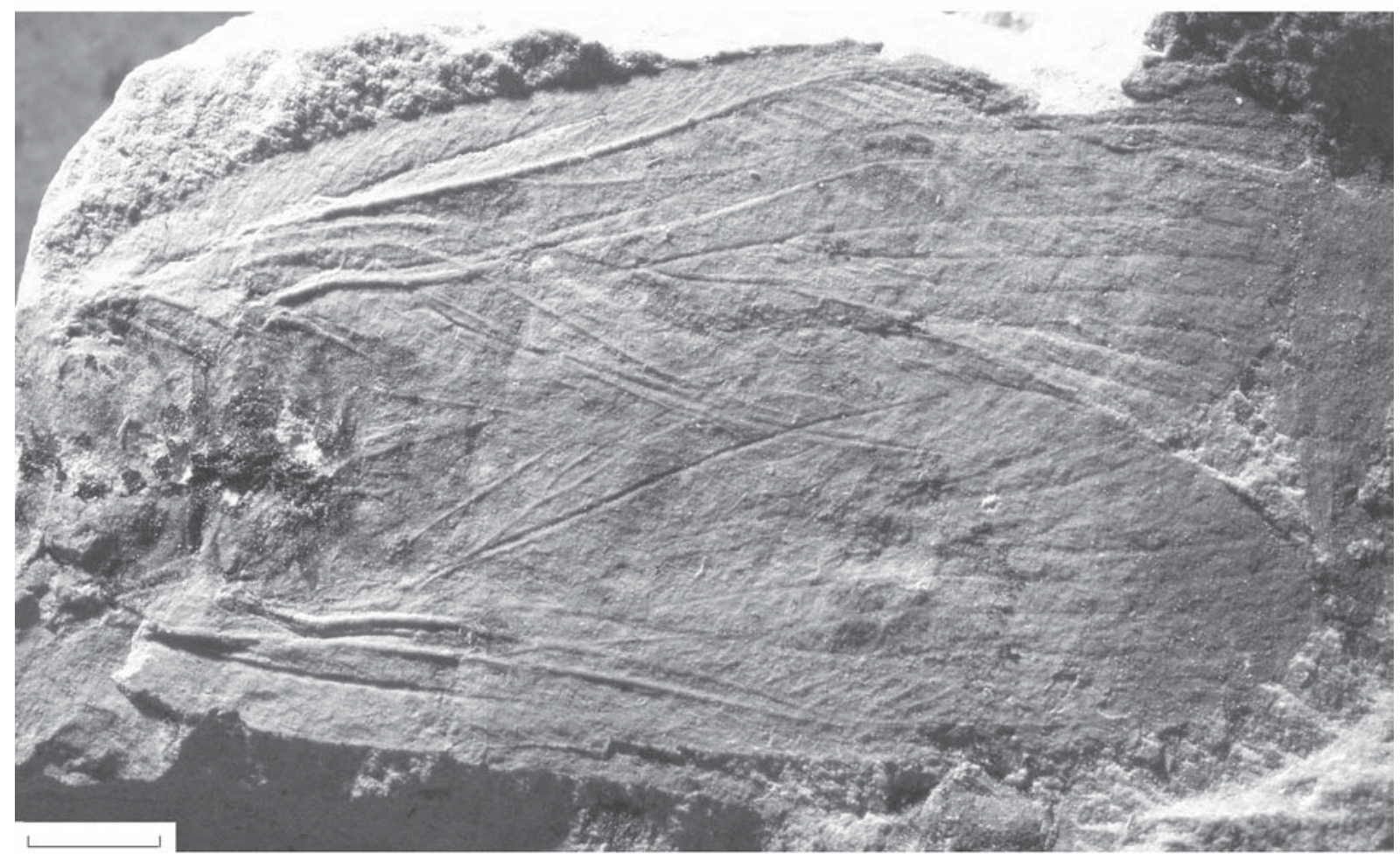

33

Figs 21-22. Chelopterum ultimus Aristov et Rasnitsyn, sp. n., Holotype, PIN, № 1700/539, habitus: 21 — positive impression; 22 negative impression. Scale bars $-2 \mathrm{~mm}$.

Рис. 21-22. Chelopterum ultimus Aristov et Rasnitsyn, sp. n., голотип, PIN, №.1700/539, общий вид: 21 — прямой отпечаток; 22 обратный отпечаток. Длина масштабной линейки 2 мм. 

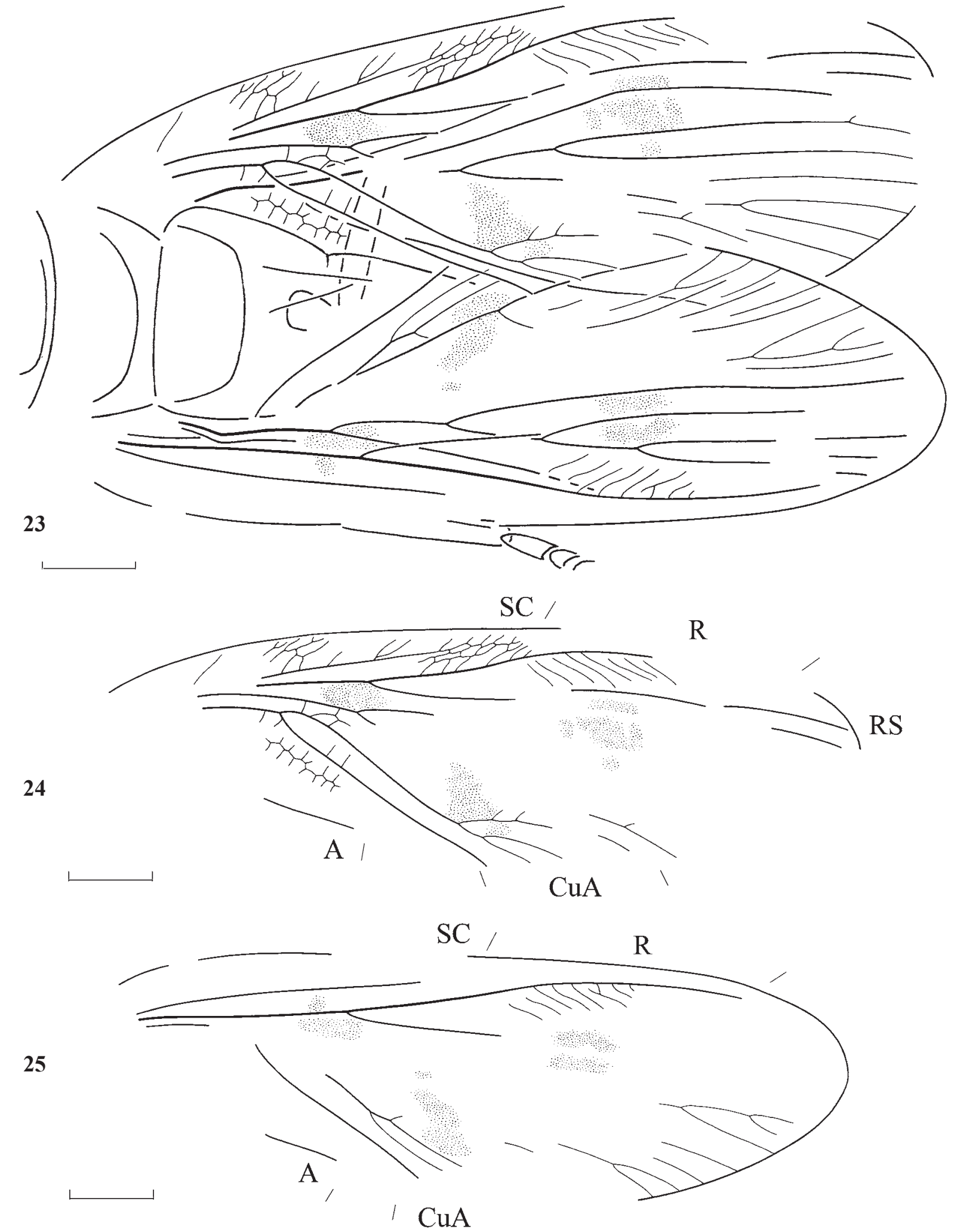

Figs 23-25. Chelopterum ultimus Aristov et Rasnitsyn, sp. n., Holotype, PIN, № 1700/539: 23 — habitus; 24-25 — fore wings. Длина масштабной линейки 2 мм.

Рис. 23-25. Chelopterum ultimus Aristov et Rasnitsyn, sp. n., голотип, ПИН, № 1700/539: 23 - общий вид; 24-25 - передние крылья. Длина масштабной линейки 2 мм. 

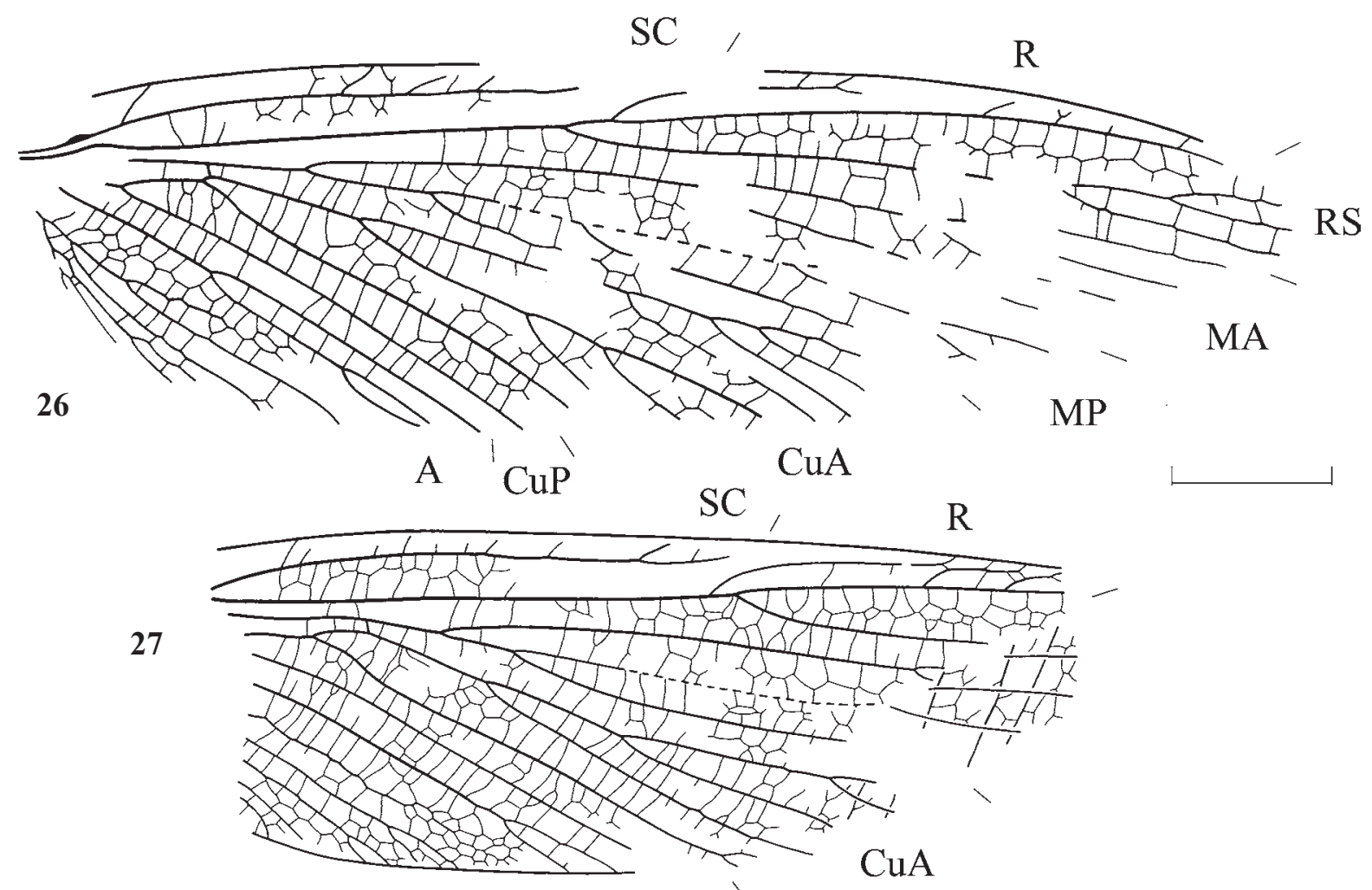

$\mathrm{A} \backslash \mathrm{CuP}$
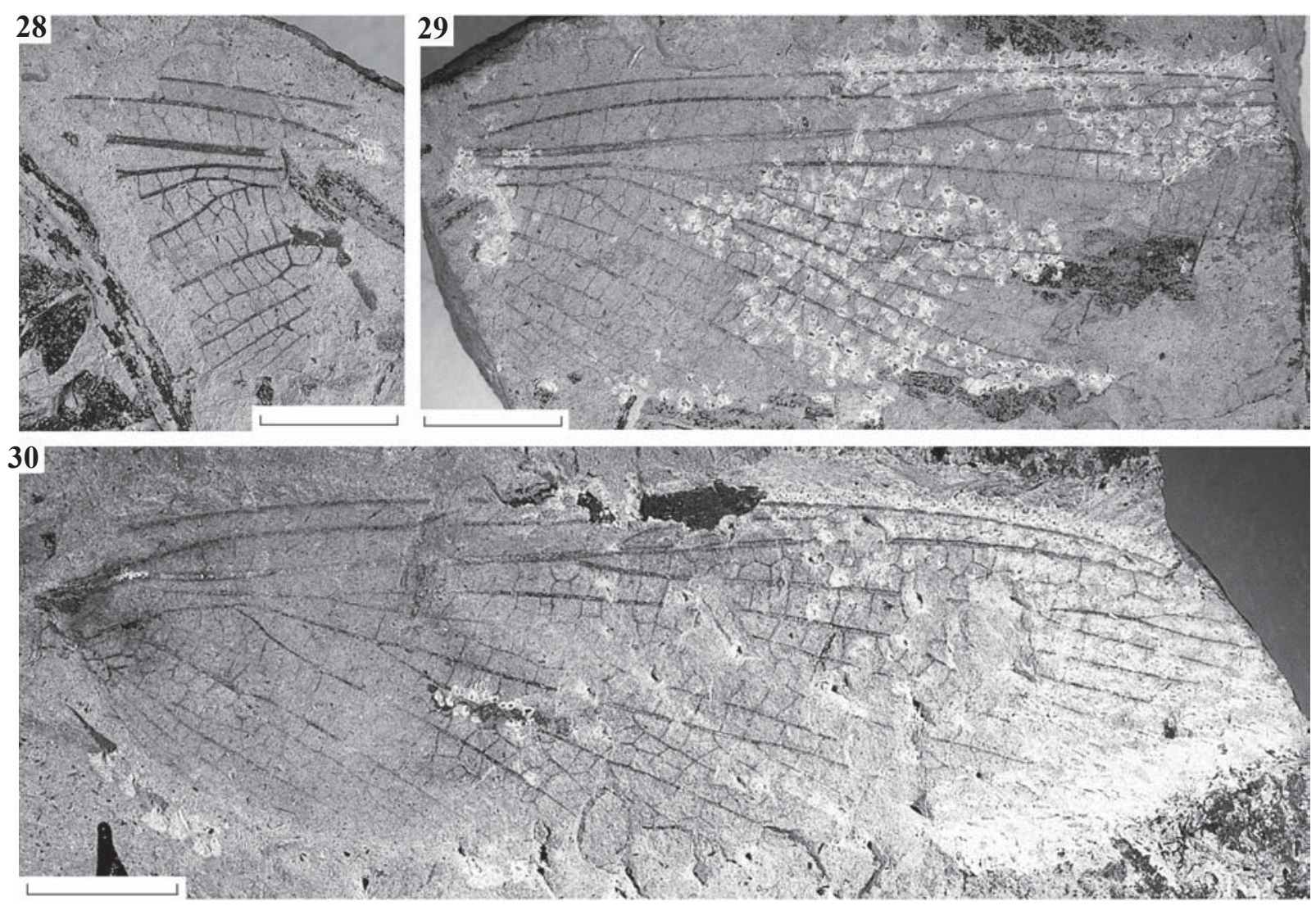

Figs 26-30. Novokshonovus ignoratus Aristov et Rasnitsyn, gen. et sp.n., fore wings: 26, 30 - Holotype PIN, № 4987/811; 27-29 Paratype PIN, № 4987/810. Scale bars — 5 мм.

Рис. 26-30. Novokshonovus ignoratus Aristov et Rasnitsyn, gen. et sp.n., передние крылья: 26, 30 — голотип ПИН, № 4987/811; 27-29 — паратип ПИН, № 4987/810. Длина масштабной линейки - 5 мм. 


\section{Ordo Phasmatida Leach, 1915}

Family Permophasmatidae Gorochov, 1992

Genus Arachnophasma Aristov et Rasnitsyn, gen. n.

TYPE SPECIES. A. scurra Aristov et Rasnitsyn, sp. n.

DESCRIPTION. Nymph with body compact and legs very long. Head transverse, hypognathous, with eyes small. Antennae and maxillary palps very long, scapes and pedicels thick and short, flagellar segments growing longer toward apex. Pronotum small, transverse, wider than head, without paranota, meso- and metanotum narrower than head, transverse. Legs thick, very long (hind tibia longer than body), fore and mid ones of subequal length, hind legs longer, femora and tibiae each of subequal width throughout, at least fore and mid femora carinate longitudinally. Tibiae narrower that femora, slightly bent, fore and mid tibiae as long as, hind ones longer and narrower than femora. Hind tarsus narrower but not longer than tibia, 5-segmented, with basitarsus longest, $4^{\text {th }}$ segment shortest, claws small and with no arolium preserved. Abdomen elongate ovoid, as long as head and thorax, wider than meso- and metathorax. Colour pattern spotted.

DIAGNOSIS. Differs from other nymphal stick insects in having short body combined with very long appendages: as far as we know, all Phasmatida have length of legs and body more or less correlated.

COMPOSITION. Type species.

ETYMOLOGY. Genus name is after arachne, the Greek for spider, and phasma, the Greek for stick insect. Gender feminine.

REMARKS. The fossil under description is identified as a nymph (either an early nymph or a nymph of a wingless insect) because of complete absence of vestiges of both wings and genitalia, combined with long multisegmented antenna and complete tarsal segmentation. Structure of the nymph is characteristic of an obligatory phytophilous insect, with antenna very long and legs clinging (all tibial apices directed forward). Taken together with the legs very long and hind femora not at all thickened basal, the fossil looks comparable only with the nymphs of stick insects, even though the latter normally have body long (or, sometimes, both body and appendages comparatively short). Additionally, the otherwise only known leg of an unidentified phasmatid in Tshekarda displays similar structure and proportion of leg segments [Gorochov, 1994: fig. 1a]. Arachnephasma is tentatively attributed to the only known Paleozoic phasmatid family Permophasmatidae. A disruptive, spotted colour pattern of the present fossil which helped it to rest hardly visible in plant thickets is known in ancient stick insects as well (cf. Cretophasmomima melanogramma Wang, Béthoux et Ren, 2014 from the Early Cretaceous Yixian Fm., NE China; Wang et al., 2014). However, this colour pattern is not specific of the stick insects among the ancient insect phytophiles [cf. Rasnitsyn \& Krassilov, 2000: fig. 2].

\section{Arachnephasma scurra Aristov et Rasnitsyn, sp. n.} Figs 31-32.

MATERIAL. Holotype. PIN, no.1700/3349, part and counterpart of complete insect; Tshekarda.

DESCRIPTION. Length of body $5.5 \mathrm{~mm}$, of hind leg 1.5 $\mathrm{mm}$. Antenna with five basal segments as long as body, seventh segment as long as head and thorax combined. Preserved maxillary palp segments abous as long and wide as fourth antennal segment. Fore and mid femora and tibiae of almost equal length (tibiae slightly shorter than respective femora), hind femur ca. 1.15 as long an mid one, hind tibia 1.15 times as long as hind femur, hind tarsus 0.8 times as long as hind tibia, proportions of tarsal segments (claws excluded) 1:0.6:0.45:0.13:0.27. Claws small, simple, weakly bent. Dark spots on pronotal sides, in apices of flagellar and tarsal segments, in pronotal sides and three equidistant in each femur and tibia (hind femora possibly without basal spot), scapes, pedicels, meso- and metanotum and fore half of abdomen darkened.

ETYMOLOGY. Species name the Latin for jester; a noun in opposition.

\section{Holometabola incertae sedis}

Genus Cavalarva Aristov et Rasnitsyn, gen. n.

TYPE SPECIES. C. caudata Aristov et Rasnitsyn, sp. $\mathbf{n}$.

DESCRIPTION. Insect larva campodeiform, with distinct hypognathous head of medium size bearing antennae with short and thick scape and pedicel and thin, elongate flagellum, and possibly with compound eyes. Thoracic segments distinctly wider than head and abdomen, of subequal size (pronotum somewhat smaller) and sclerotization, bearing short 4-segmented legs with paired claws and lacking wing pads. Abdomen straight, moderately elongate, gradually narrowing rearward, with 7 visible segments showing no free pleural sclerites, with no appendages preserved other than two long and very thin, apparently multisegmented caudal threads.

TAXONOMIC POSITION. The fossil at hand is a molting cast of immature insect which almost doubtless represents a holometabolan larva because of characteristic general appearance with no wing and genital vestiges and with short, thick legs of general structure typical of slowly moving insect larvae (segments short with coxa the biggest and with no knee bent well expressed). No likely alternative is apparently available, for no other insect taxa demonstrate a comparable leg construction. At the same time, some other important features of the new genus are unique for the holometabolan larvae, and particularly 7-segmented abdomen bearing a pair of long, multisegmented caudal threads. Similar abdominal appendages are known in some beetle larvae (for instance, in Carabidae and Staphylinidae), but even externally they never occur basal of eight abdominal segment. Highly unusual are also four-segmented legs with paired claws. Concerning the compound eyes possibly present in the larva in question, these are well known to exist in living scorpionflies. However, the latter always have abdomen with more segments and never with caudal thread. Taking into account also a wide diversity of unidentified but potentially high ranked fossils recorded in the Tshekarda fossil assemblages [Aristov, 2015], as well as presence of higher ranked holometabolans with unknown immatures (even including orders such as Palaeomanteida and Glosselytrida), it is safer to treat the new genus as Holometabola incertae sedis.

COMPOSITION. Type species.

ETYMOLOGY. Genus name is after cava, the Latin from empty, and larva. Gender feminine.

\section{Cavalarva caudata Aristov et Rasnitsyn, sp. n. Figs 33-35.}

MATERIAL. Holotype. PIN, no.1700/2205, part and counterpart of complete moulting case of insect larva; Tshekarda.

DESCRIPTION. Body length $9 \mathrm{~mm}$. General colour moderately dark, with head capsule possibly more dark in parts. Details of head capsule structure obscure. Scape elon- 
gate, pedicel transverse, both near as wide as third leg segment, flagellum as preserved at most half as wide as these, of uniform width. Pronotal half-tergum about as long as, and 0.7 as wide as meso- and metanotal ones, all three somewhat widening rearward. Leg segments narrowing apical, with obscure homology except basal one (coxa). Coxa conical, $2^{\text {nd }}$ segment near parallel-sided, elongate, $3^{\text {rd }}$ transverse, obconical, terminal (tarsal or tibiotarsal) elongate, slightly widened apical, claws about as long as terminal segment wide, narrow and slightly bent. Abdominal terga and sterna near rectangu-

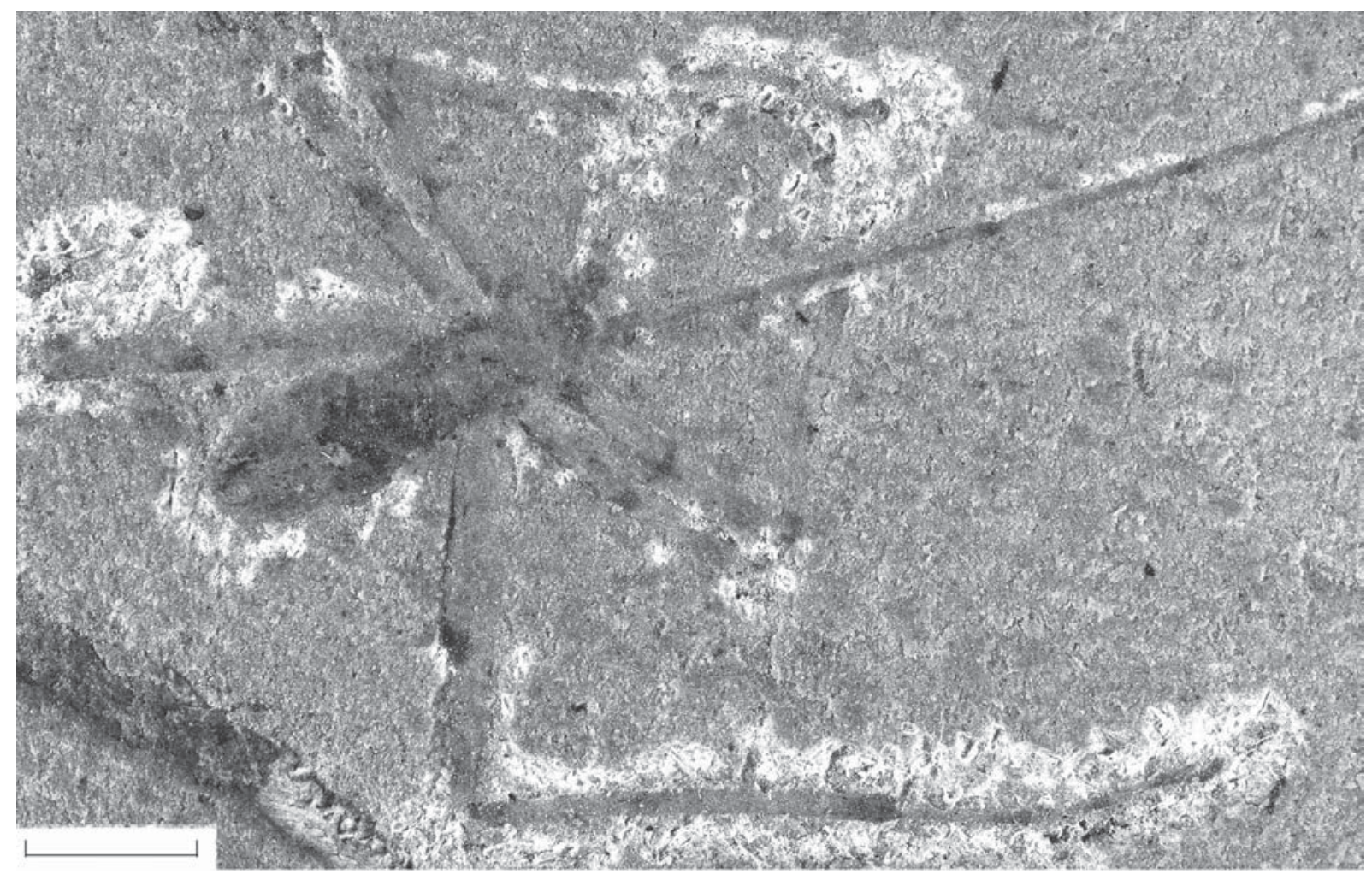

31

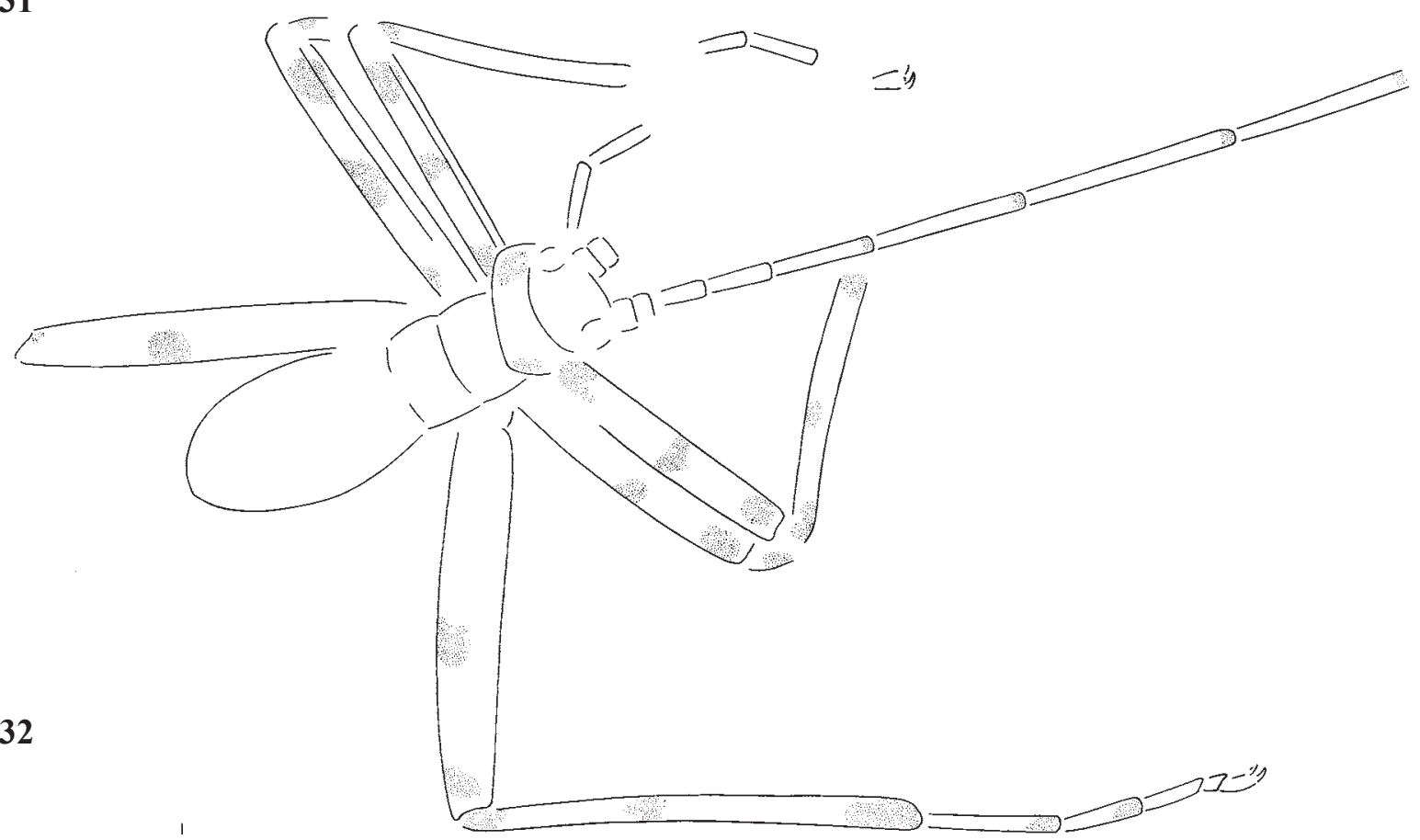

Figs 31-32. Arachnophasma scurra Aristov et Rasnitsyn, gen. et sp. n., Holotype. PIN, №1700/3349, general view. Scale bars 2 mm. Рис. 31-32. Arachnophasma scurra Aristov et Rasnitsyn, gen. et sp. n., голотп, ПИН, № 1700/3349, общий вид. Длина масштабной линейки 2 мм. 


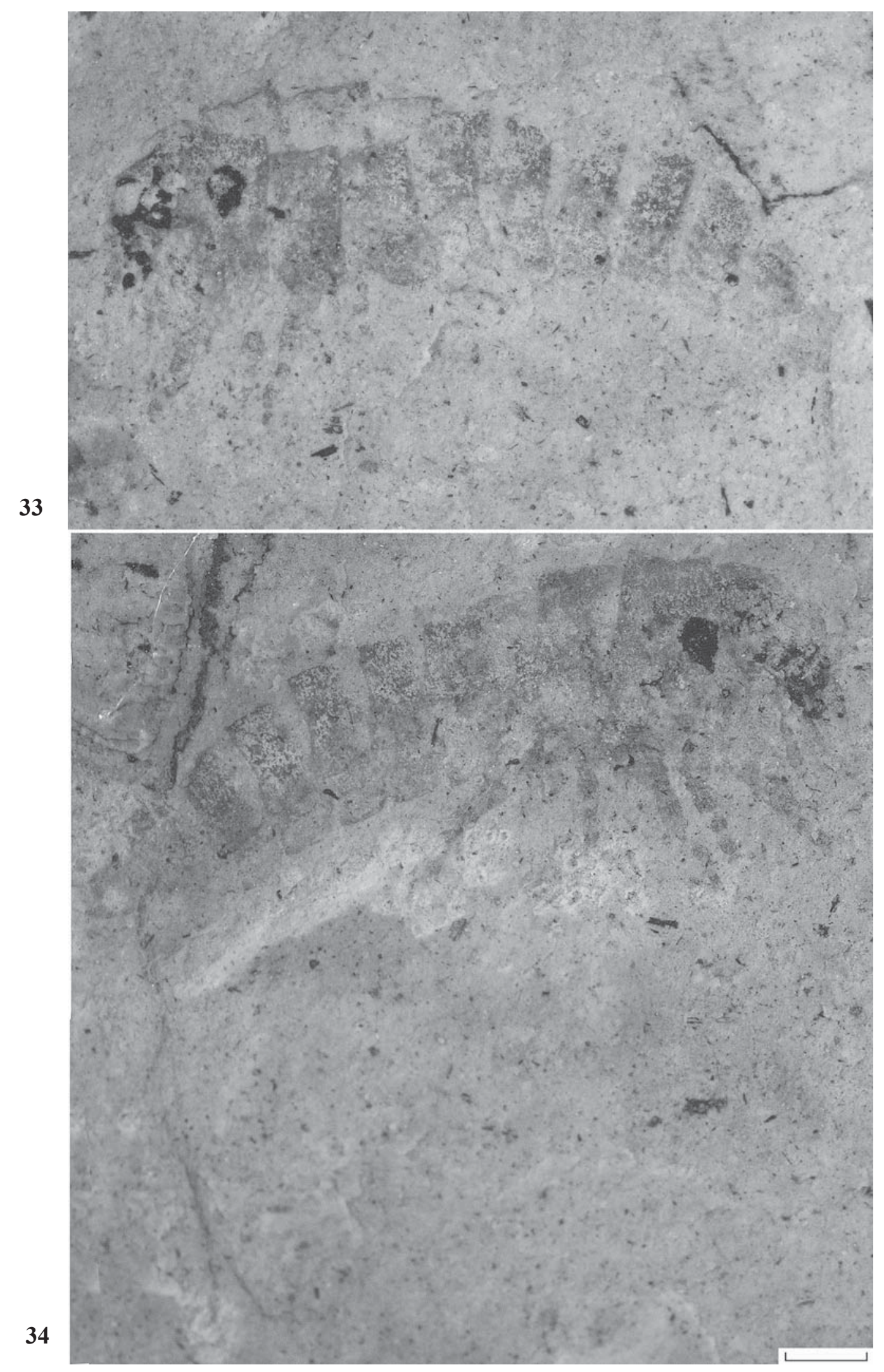

Figs 33-34. Cavalarva caudata Aristov et Rasnitsyn, gen. et sp. n., Holotype. PIN, № 1700/2205, habitus: 33 — positive impression; 34 - negative impresion. Scale bars $1 \mathrm{~mm}$.

Рис. 33-34. Cavalarva caudata Aristov et Rasnitsyn, gen. et sp. n., Holotype. PIN, №1700/2205, общий вид: 33 — прямой отпечаток; 34 - обратный отпечаток. Длина масштабной линейки 1 мм. 
lar in side view and of subequal length, except for shorter penultimate and particularly ultimate ones, $7^{\text {th }}$ (apical) tergum being 1.5 times as long lateral as medial. Caudal filaments about as long as abdomen, scarcely narrowing apical, about as wide as antennal flagellum, seemingly attached near to base of apical abdominal tergum (unless due to deformation of molting cast).

ETYMOLOGY. Species name is the Latin for tailed.

\section{References}

Aristov D.S. 2004. The Fauna of Grylloblattid Insects (Grylloblattida) of the Lower Permian Locality of Tshekarda. // Paleontological Journal. Vol.38. Suppl.2. P.80-145.

Aristov D.S. 2009. Review of the stratigraphic distribution of Permian Grylloblattida (Insecta), with descriptions of new taxa // Paleontological Journal. Vol.43. No.6. P.643-651.

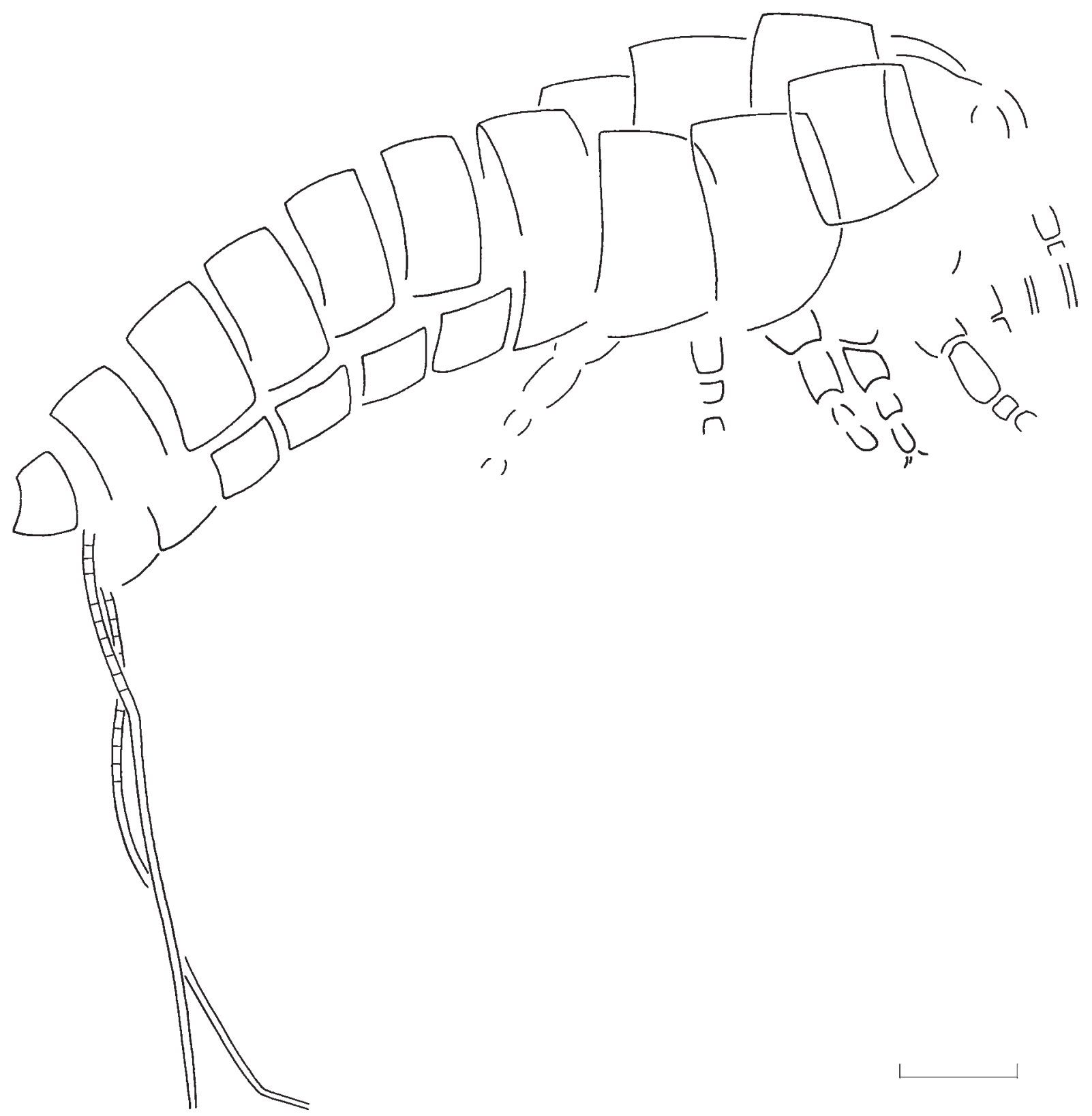

Fig. 35. Cavalarva caudata Aristov et Rasnitsyn, gen. et sp. n., Holotype. PIN, № 1700/2205, reconstruction. Scale bar - $1 \mathrm{~mm}$.

Fig. 35. Cavalarva caudata Aristov et Rasnitsyn, gen. et sp. n., Holotype. PIN, № 1700/2205, реконструкция. Длина масштабной линейки 1 мм. 
Aristov D.S. 2011. Morphology of some Permian Grylloblattida (Insecta) from the Chekarda locality (Perm Region) // Modern paleonology: classical and new methods. Moscow: PIN RAS. P.25-34.

Aristov D.S. 2014a. New taxa of Mesorthopteridae (Insecta: Grylloblattida) from the Permian of Russia // Paleontological Journal. Vol.48. No.5. P.488-499.

Aristov D.S. 2014b. Classification of the order Cnemidolestida (Insecta; Perlidea) with description of new taxa // Far Eastern Entomologist. No.277. P.1-46.

Aristov D.S. 2015. Phylum Arthropoda // L.V. Zhuzhgova, G.Yu. Ponomareva, D.S. Aristov, S.V. Naugolnykh (eds.). [Outcrop Chekarda - locality of Permian fossil insects and plants]. Perm: ZAO "Tipographia". 2015. [in Russian].

Beckemeyer R.J. \& Hall J.D. The entomofauna of the Lower Permian fossil insect beds of Kansas and Oklahoma, USA // African Invertebrates. Vol.48. No.1. P.23-39.

Béthoux O., Gu J.-J., Ren D. 2012. A new Upper Carboniferous stem-orthopteran (Insecta) from Ningxia (China) // Insect Science. No.19. P.153-158.

Carpenter F.M. 1944. Carboniferous insects from the vicinity of Mazon Creek, Illinois. // Illinois State Museum, Scientific Papers. Vol.3. No.1. P.1-20.

Cui Y.Y., Béthoux O., Ren D. 2011. Intraindividual variability in Sinonamuropteridae forewing venation (Grylloblattida; Late Carboniferous): taxonomic and nomenclatural implications // Systematic Entomology. Vol.36. P.44-56.

Gorochov A.V. 1994. Permian and Triassic walking sticks (Phasmoptera) from Eurasia // Paleontological Journal. Vol.28. No.4. P.83-98.

Kukalová J. 1964. Permian insects of Moravia. Pt.2. Liomopteridae // Sbor. geol. ved. paleontol. T.3. P.39-118.
Novokshonov V.G. 1998. Fossil insects of the Chekarda // Ponomareva G.Yu., Novokshonov V.G., Naugol'nykh S.V. ChekardaPermian plants and insects locality. Perm: Perm University. 92 p. [in Russian]

Novokshonov V.G. 2000. New Fossil Insects (Insecta: Grylloblatti$\mathrm{da}$, Ordinis Incertis) from the Lower Permian of the Middle Urals // Paleontological Journal. Vol.34. No.5. P.42-47.

Novokshonov V.G. \& Aristov D.S. 2004. New Taxa of Hypoperlids (Insecta: Hypoperlida) from the Upper Permian of the Arkhangelsk Region // Paleontological Journal. Vol.38. No.1. P.60-66.

Rasnitsyn A.P., Aristov D.S., Rasnitsyn D.A. 2013. Insects of the Permian and Early Triassic (Urzhumian-Olenekian Ages) and the Problem of the Permian-Triassic Biodiversity Crisis // D.S. Aristov et al. Fossil Insects of the Middle and Upper Permian of European Russia. Paleontological Journal. Vol.47. No.7. P.793-823.

Rasnitsyn A.P., Aristov D.S., Rasnitsyn D.A. 2015. Dynamics of the taxonomic diversity of insects in the Early and Middle Permian // Paleontological Journal. Vol.49. No.12 (in press).

Rasnitsyn A.P., Krassilov V.A. 2000. First paleontologically confirmed phyllophagy of pre-Cretaceous insects: leaf tissues in the guts of the Upper Jurassic insects from Karatau (Kazakhstan) // Paleontological Journal. Vol.34. No.3. P.301-309.

Storozhenko S.Yu. 1998. [Sistematics, phylogeny and evolution of the grylloblattids (Insecta: Grylloblattida)]. Vladivostok: Dalnauka. 207 pp. [in Russian].

Wang M., Béthoux O., Bradler S., Jacques F.M.B., Cui Y. et al. 2014. Under Cover at Pre-Angiosperm Times: A Cloaked Phasmatodean Insect from the Early Cretaceous Jehol Biota // PLoS ONE. Vol.9. No.3. e91290. doi:10.1371/journal.pone.0091290. 